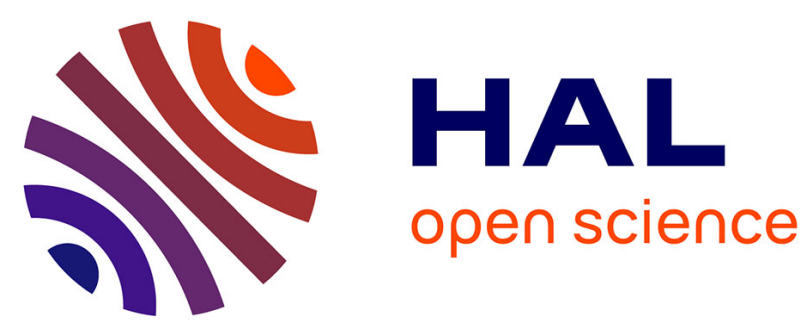

\title{
Multiple oxidation state trace elements in suboxic waters off Peru: In situ redox processes and advective/diffusive horizontal transport
}

Gregory A Cutter, James Moffett, Maria C Nielsdóttir, Virginie Sanial

\section{- To cite this version:}

Gregory A Cutter, James Moffett, Maria C Nielsdóttir, Virginie Sanial. Multiple oxidation state trace elements in suboxic waters off Peru: In situ redox processes and advective/diffusive horizontal transport. Marine Chemistry, 2018, 201, pp.77-89. 10.1016/j.marchem.2018.01.003 . hal-02510973

\author{
HAL Id: hal-02510973 \\ https://hal.science/hal-02510973
}

Submitted on 18 Mar 2020

HAL is a multi-disciplinary open access archive for the deposit and dissemination of scientific research documents, whether they are published or not. The documents may come from teaching and research institutions in France or abroad, or from public or private research centers.
L'archive ouverte pluridisciplinaire HAL, est destinée au dépôt et à la diffusion de documents scientifiques de niveau recherche, publiés ou non, émanant des établissements d'enseignement et de recherche français ou étrangers, des laboratoires publics ou privés. 


\title{
Cutter, G. A., Moffett, J. G., Nielsdóttir, M. C. and Sanial, V. (2018) Multiple oxidation state trace elements in suboxic waters off Peru: In situ redox processes and advective/diffusive horizontal transport, Marine Chemistry, 201, 77-89, doi:10.1016/j.marchem.2018.01.003,
}

\author{
Multiple oxidation state trace elements in suboxic waters off Peru: In situ \\ redox processes and advective/diffusive horizontal transport
}

\author{
Gregory A. Cutter ${ }^{\mathrm{a}, *}$, James G. Moffett ${ }^{\mathrm{b}}$, Maria C. Nielsdóttir ${ }^{\mathrm{a}}$, Virginie Sanial ${ }^{\mathrm{c}}$ \\ ${ }^{a}$ Department of Ocean, Earth, and Atmospheric Sciences, Old Dominion University, Norfolk, VA 23529, USA \\ b Department of Biological Sciences, University of Southern California, Los Angeles, CA 90089, USA \\ ${ }^{\mathrm{c}}$ Department of Marine Chemistry and Geochemistry, Woods Hole Oceanographic Institution, Woods Hole, MA 02543, USA
}

\section{A R T I C L E I N F O}

\section{Keywords:}

Redox

Trace elements

Oxygen minimum zone

Horizontal transport

\begin{abstract}
A B S T R A C T
Oxygen minimum zones (OMZs), where the concentrations of oxygen are at analytical detection limits, but sulfate reduction is not occurring, are termed suboxic and typically nitrate serves as the terminal electron acceptor for heterotrophic respiration. Such respiration is highest near the top of OMZs where maxima in nitrite and other redox active species are observed. Within OMZs, the availability of free electrons for reduction reactions ( $\mathrm{p} \varepsilon$ ) can range from -2 to 10 and at thermodynamic equilibrium could control the oxidation states of essential trace elements like iron and toxic ones like arsenic. In turn, this oxidation/reduction speciation affects trace element solubility and bioavailability, thus controlling their reactivity and transport. Field observations and mesoscale models demonstrate the increasing areal extent of oxygen minimum zones, but whether this in turn affects trace element cycling and fluxes remains to be verified. From current observations, it is difficult to determine the relative importance of in situ processes and lateral transport from boundaries to trace elements' redox cycling, which are typically highly redox- and biologically-active in these systems. Such processes could lead to the co-occurrence of redox species that are not controlled by a unique pe. In order to evaluate the effects of in situ redox processes versus advective/diffusive transport on trace elements, the cycling of nitrate/nitrite, iodate/iodide, $\mathrm{Fe}(\mathrm{II}), \mathrm{As}(\mathrm{III}) / \mathrm{As}(\mathrm{V})$, and hydrogen sulfide was examined in the low oxygen waters off the Peru shelf to the open South Pacific Ocean during the US GEOTRACES GP16 transect in 2013. Nitrite, Fe(II), and iodide were observed from the shelf to $95^{\circ} \mathrm{W}$, while reduced forms of sulfur and arsenic were absent. Maxima in nitrite, Fe(II) and iodide were coincident, indicating the utilization of Fe(III), iodate and nitrate as terminal electron acceptors was possible. For iron, this finding was unexpected with regards to thermodynamics. However, closer inspection combined with advective/diffusive modeling of water column data and ${ }^{228} \mathrm{Ra}$-based flux calculations, showed that benthic redox processes, coupled with westward isopycnal transport, influenced the chemical composition and redox speciation within the upper OMZ well offshore. This horizontal transport contributed to the coexistence of Fe(II) with nitrate, indicating that Fe redox chemistry is under kinetic, rather than thermodynamic, control.
\end{abstract}

\section{Introduction}

Oxidation-reduction reactions are the key to life on Earth and perhaps one of best known redox reactions is described in the Redfield equation (Redfield et al., 1963) - the balance between photosynthesis and respiration and a cornerstone of biogeochemistry (Cutter, 2005). Moving below the ocean's euphotic zone where photosynthesis (autotrophy) and respiration (heterotrophy) are tightly coupled, respiration becomes a predominant process. This leads to a more reducing environment that can be quantified by the term $\mathrm{p} \varepsilon$, which is the activity of a hypothetical solvated electron, analogous to $\mathrm{pH}$ (Stumm and Morgan,
1996). For the modern ocean, the two extremes of respiration are in the oxic water column where oxygen is the ultimate terminal electron receptor (pe ca. 13) and in anoxic basins such as the Black Sea where the terminal electron acceptor is sulfate (p $\varepsilon$ ca. -4 ), with hydrogen sulfide (and its related chemical species) being the product. However, the wide redox conditions between these two extremes, frequently termed 'suboxia' are not only found in the modern ocean, but are also more widespread than sulfidic waters $(0.2 \%$ of the ocean's volume; Codispoti et al., 2005) and in fact are growing in spatial coverage (Matear and Hirst, 2003; Stramma et al., 2008). Suboxia has profound effects on the solubility and therefore transport of many biologically-important trace

\footnotetext{
* Corresponding author

E-mail address: gcutter@odu.edu (G.A. Cutter).
} 
elements (e.g., Fe; Moffett et al., 2007, Moffett et al., 2015). The chemical speciation and solubility of these essential and other trace elements depends on the actual redox poise of the waters (i.e., the $p \varepsilon$ ), which varies with depth and location due to the concentrations of the various potential terminal electron acceptors (oxygen, nitrate, iodate, $\mathrm{Mn}(\mathrm{V}), \mathrm{Fe}(\mathrm{III})$, etc.; Codispoti et al., 2005) and whether the element itself is the terminal electron acceptor.

The first detailed description of suboxia in marine waters was that of Richards (1965), who roughly defined it as the region where oxygen concentrations are vanishingly small, but before sulfate reduction occurs (anoxia). Under these conditions, a variety of oxidants can be used as terminal electron acceptors. The canonical sequence of these oxidants used by heterotrophs in respiration was given by Stumm and Morgan (1996). In this sequence, after oxygen (the strongest oxidant, leading to a $\mathrm{p} \varepsilon$ in average seawater of 12.8), denitrification would follow, then reduction of Mn(IV) oxides, then iron oxide reduction, and finally sulfate reduction occurs and the system becomes anoxic ( $p \varepsilon$ of -4 in average seawater). It is important to note that this sequence is really one of free energy change, with organic matter oxidation via oxygen releasing the most and via sulfate the least. Not surprisingly, the actual sequence is much more complicated, largely because the abundance of the oxidants considered by Stumm and Morgan (1996) are much lower (e.g., oxides of manganese and iron), while others such as iodate are higher or were not even considered. Based on works in suboxic waters of the Black Sea (e.g., Luther and Campbell, 1991) and Arabian Sea (e.g., Farrenkopf et al., 1997), Codispoti et al. (2005) proposed that the energy sequence of terminal electron acceptors for oxic to anoxic respiration is $\mathrm{O}_{2}>\mathrm{IO}_{3}{ }^{-}>\mathrm{NO}_{3}{ }^{-}>\mathrm{Mn}(\mathrm{IV})>\mathrm{Fe}$ (III) $>\mathrm{SO}_{4}{ }^{2-}$. This list is missing other potential oxidants whose standard potentials are in the range of these "established" redox couples. Moreover, many other low concentration trace elements with redox behavior (e.g., cobalt) may change speciation in response to the wide $p \varepsilon$ imposed by this sequence (i.e., suboxic $p \varepsilon$ varies from ca. 10 to -2). However, redox transformations occur not only in the water column, but also within sediments where the sediment/water exchange and horizontal transport could affect the abundances of dissolved redox species and therefore the apparent $\mathrm{p} \varepsilon$ of these waters.

The behavior of nitrogen in oxygen minimum zone (OMZ) waters has received considerable attention (e.g., Codispoti and Packard, 1980; Lipshultz et al., 1990; Naqvi et al., 1990; Deutsch et al., 2001) and in most oceans nitrate is the primary terminal electron acceptor for suboxic respiration (Codispoti et al., 2005). However, as noted above, nitrogen is not the only player. Therefore, rather than reviewing its cycle, attention here will be paid to other redox couples that can potentially reveal the redox state/poise of the suboxic water column. To put these couples in perspective, Fig. 1 contains a modified version of Stumm and Morgan's (1996) classic redox diagram as proposed from thermodynamic calculations and supplemented by field observations of Rue et al. (1997), but with arsenic added.

Oxygen will always dominate redox thermodynamics even at micromolar concentrations that represent typical analytical detection limits for both chemical and sensor-based methodologies. This consideration introduces considerable uncertainty unless a system is overwhelmed by hydrogen sulfide or it can be proven that oxygen is completely absent. Recent measurements of dissolved oxygen enabled by STOX sensors in the Peruvian OMZ (Revsbech et al., 2009; Tiano et al., 2014) reveal that dissolved $\mathrm{O}_{2}$ levels are $<10 \mathrm{nmol} \mathrm{l}^{-1}$, much lower than the micromolar detection levels of conventional sensors or chemical assays. Tiano et al. (2014) argued that with detection limits this low, these waters are "functionally anoxic". Indeed, it seems unlikely that oxygen could be poised at the low nanomolar level over hundreds of meters and is probably truly zero. In interpreting our findings, we assume that observations made by others in the same study region with STOX sensors hold true here.

Iodine. Some of the earliest examinations of iodine cycling in the ocean (e.g., Wong and Brewer, 1974) found fully oxidized iodate to

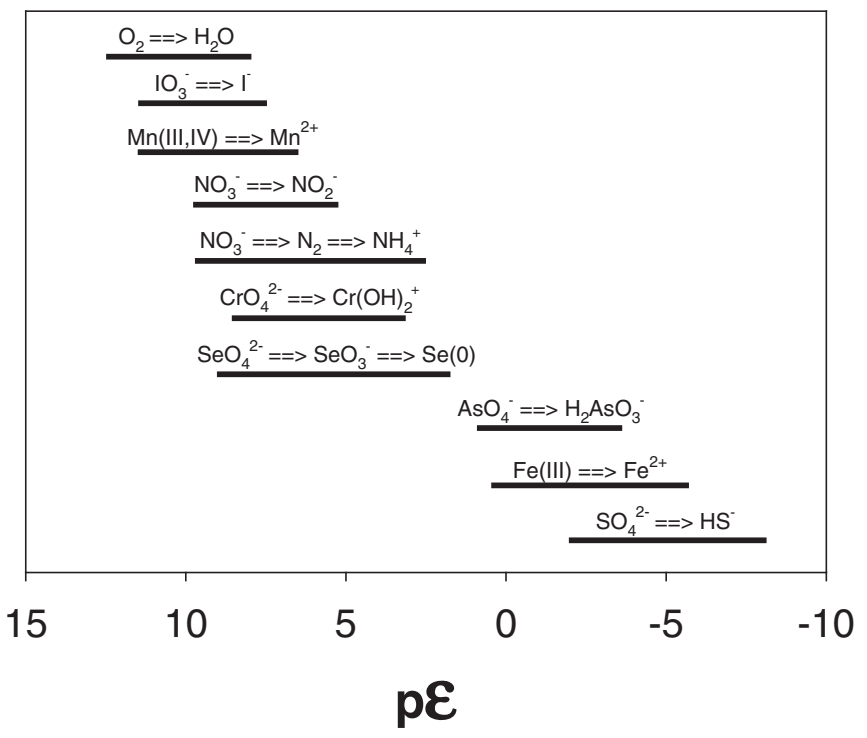

Fig. 1. Predicted $\mathrm{p} \varepsilon$ ranges for redox couples in seawater at $\mathrm{pH} 7.5$ and 35 salinity (adapted from Rue et al., 1997 with the addition of As). The p $\varepsilon$ for each redox reaction is given as a range due to variations in seawater concentrations and activities of any solid phases. Note that the vertical scale is relative, but represents the relative differences in free energy change for the reduction reaction.

have nutrient-like depth profiles similar to phosphate $(\mathrm{r}=0.95$; atomic $\mathrm{I} / \mathrm{P}=0.04$; Wong and Brewer, 1974). The redox chemistry of iodine, specifically the iodate/iodide $\left(\mathrm{IO}_{3}{ }^{-} / \mathrm{I}^{-}\right)$couple, was originally discussed by Wong and Brewer (1977). Its behavior in suboxic waters was studied by Luther and Campbell (1991) in the ca. $80 \mathrm{~m}$ suboxic zone of the Black Sea, the Arabian Sea (Farrenkopf et al., 1997; Farrenkopf and Luther, 2002), and the eastern tropical North Pacific off Mexico where the OMZ extends from 140 to $600 \mathrm{~m}$ depth (Rue et al., 1997). In anoxic basins Wong and Brewer (1977) observed the quantitative conversion of iodate to iodide, but Rue et al. (1997) discovered that the iodate deficit from reduction was quantitatively matched with an iodide maximum in suboxic waters. This quantitative conversion combined with examinations of the mixing behavior in the suboxic interval (T-S diagrams; Rue et al., 1997), suggests that iodate reduction occurs in situ and is minimally affected by horizontal transport from reducing sediments. In contrast, the latter had to be invoked in the Arabian Sea (Farrenkopf and Luther, 2002). Of course sediment sink/sources and horizontal mixing must be considered for any chemical feature in the water column, but iodine has an advantage over many other redox tracers in that both the reduced and oxidized species are monovalent anions and not very particle reactive - they stay in the dissolved state with no phase conversions. Moreover, high iodate concentration $(500 \mathrm{nmol} / \mathrm{L})$ suggests that it can serve as an electron acceptor in suboxic respiration, a role confirmed by Farrenkopf et al. (1997). The predictions in Fig. 1 suggest that the iodine couple would show redox conversions in the region just before manganese oxide reduction and denitrification and thus serve as the first indicator of suboxia before $\mathrm{N}$ conversions.

Arsenic. Dissolved arsenic is found in two primary oxidation states, $\mathrm{As}(\mathrm{V})$, or arsenate, and As(III) as arsenite. Arsenic is toxic to marine phytoplankton, which is enhanced by its chemical similarity to phosphate and the effect of As(V/III) redox chemistry and methylation on toxicity (e.g., Wurl et al., 2013). Arsenic redox chemistry has been examined in a number of anoxic basins (e.g., Saanich Inlet, Peterson and Carpenter, 1983; eastern Mediterranean, Van der Weijden et al., 1990; Black Sea, Cutter, 1991). In the process of studying these more extreme redox environments, it has been found that the $\mathrm{V}$ to III reduction occurs just above the anoxic/sulfidic zone - in the suboxic water column. Oremland and Stolz (2003) reported that many bacteria 


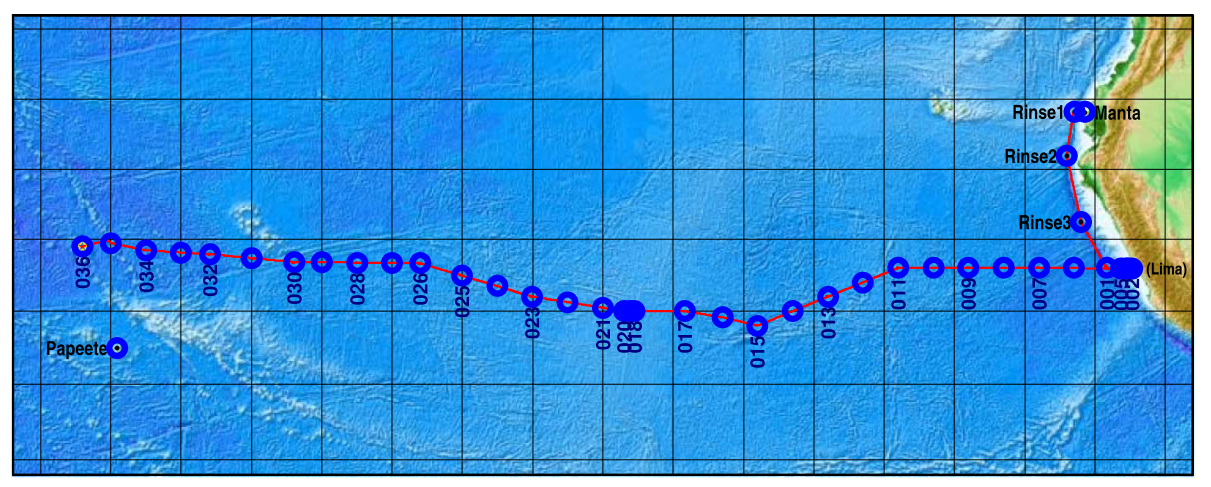

Fig. 2. Cruise track for US GEOTRACES Cruise GP16 from Manta, Ecuador to Papeete, Tahiti, 25 October-20 December 2013 using RV Thompson and showing all stations were vertical profiles were obtained.

\section{GEOTRACES-EPZT Cruise Track 2013-12-18 05:43 UTC}

can use arsenate as a terminal electron acceptor in respiration, and since As is ca. $20-30 \mathrm{nmol} / \mathrm{L}$ in seawater (e.g., Cutter and Cutter, 2006), the arsenate/arsenite redox couple can be placed on Fig. 2 near Fe(III) reduction, but well before sulfate reduction. Moreover, like iodine, both members of the As redox couple are oxyanions and of lesser reactivity (arsenate is scavenged by iron oxides; Cutter, 1991), so As(V)/As(III) presents itself as an important couple in the characterization of suboxic conditions.

Iron. The geochemistry of iron is dominated by its redox cycle since $\mathrm{Fe}(\mathrm{III})$ forms insoluble hydroxides and oxides, and $\mathrm{Fe}(\mathrm{II})$ is a highly soluble divalent cation (Raiswell and Canfield, 2012; Moffett, 2001). In oxygenated seawater $\mathrm{Fe}(\mathrm{III})$ is favored, hence concentrations of dissolved Fe are exceedingly low in the modern ocean. From Fig. 1, Fe(II) would only be expected to prevail in waters free of oxygen and nitrate. However, steady state concentrations of $\mathrm{Fe}(\mathrm{II})$ have been reported in surface waters due to photoreduction, where it is under kinetic control (Croot and Laan, 2002, Shaked, 2008). Fe(II) is also a persistent feature in all three of the world's OMZs, where it is coincident with the secondary nitrite maximum (Hopkinson and Barbeau, 2007; Moffett et al., 2007; Vedamati et al., 2014; Kondo and Moffett, 2015; Moffett et al., 2015). The concentration of dissolved Fe concentrations on the Peruvian shelf is exceedingly high (Bruland et al., 2005) because it is predominantly present as Fe(II) (Hong and Kester, 1986; Vedamati et al., 2014). Under these conditions, it is presumably also under kinetic control, with formation and transport processes balanced by oxidation by such oxidants as nitrite and nitrate (Scholz et al., 2016). Fe(II) is unlikely to be formed in the presence of nitrate for thermodynamic reasons (Fig. 1), but it may be formed in nitrate-free microenvironments within sinking particles, where Fe(III) utilized as a terminal acceptor in respiration, or by reaction with reduced sulfur associated with a 'cryptic' sulfur cycle (Canfield et al., 2010). Such sinking particles, undergoing regeneration, may be important Fe sources as well. Fe(II) may also be formed in reducing sediments and transported offshore along isopycnals. Benthic sources of iron are important worldwide (Elrod et al., 2004; Lam and Bishop, 2008; Dale et al., 2015; Moore and Braucher, 2008) and are particularly important in reducing regimes.

The suite of redox couples reviewed above provide a useful tool for examining oxidation/reduction reactions in the OMZ off Peru that has been shown to be spatially and temporally variable (Fiedler and Talley, 2006; Czeschel et al., 2015). In particular, the redox sequence depicted in Fig. 1 suggests that once oxygen is depleted to a level unavailable to heterotrophic microorganisms, the redox sequence should be iodate reduction $>$ nitrate reduction $>$ iron (III) reduction $\simeq$ arsenate reduction $>$ sulfate reduction. As part of the 2013 US GEOTRACES GP16 zonal transect from Peru to Tahiti (Fig. 2), the redox sequences of dissolved iodate/iodide, nitrate/nitrite, arsenate/arsenite, $\mathrm{Fe}(\mathrm{III}) / \mathrm{Fe}$ (II), and sulfate/sulfide were examined to study the in situ redox processes affecting these elements/redox couples. Their water column behaviors were then compared to their changes derived elsewhere and horizontally transported to the study sites. These in situ processes versus advective/diffusive transport are crucial to assessing the actual redox processes affecting trace elements at a given site.

\section{Field sites and methods}

\subsection{Field sites and sampling methods}

Samples were taken during the US GEOTRACES Eastern Pacific Zonal Transect (International GEOTRACES GP16) starting in Ecuador on 25 October and ending in Tahiti on 20 December 2013 (Fig. 2) on board R/V Thomas G. Thompson. Samples were from the US GEOTRACES trace metal-clean carousel (Cutter and Bruland, 2012) that is equipped with a Seabird CTD with calibrated pressure/depth, temperature, conductivity/salinity, and oxygen sensors, as well as fluorometer and transmissometer. The carousel holds $2412 \mathrm{~L}$ GO-FLO bottles, two of which are closed at each depth during a $3 \mathrm{~m} / \mathrm{min}$ ascent rate to minimize metal contamination (Cutter and Bruland, 2012). After recovery, the GO-FLO bottles were transferred from the carousel into the clean lab and the water was pressure filtered using 6 psi nitrogen. The sample waters passed through $0.2 \mu \mathrm{m}$ syringe filters and into $60 \mathrm{~mL}$ polypropylene/polyethylene rubber-free syringes (Air-Tite, VWR) fitted with 3-way polycarbonate Luer valves to remove air from filling and avoid contact with the atmosphere before analyses. Three sets of syringes were filled in this fashion for Fe(II), iodide/iodate, and dissolved hydrogen sulfide determinations. Samples for arsenite/arsenate determinations were pressure filtered through $0.45 \mu \mathrm{m}$ polysulfone filters into $250 \mathrm{~mL}$ FEP Teflon bottles and immediately refrigerated for analyses within $24 \mathrm{~h}$ of collection.

\subsection{Analytical methods}

\subsubsection{Oxygen}

Dissolved oxygen analyses were performed on samples from the conventional CTD/rosette sampler with an automated oxygen titrator using photometric endpoint detection based on the absorption of $365 \mathrm{~nm}$ wavelength ultra-violet light. This apparatus uses a wholebottle modified-Winkler titration following the technique of Carpenter (1965) with modifications by Culberson (1994).

\subsubsection{Nutrients}

Nutrient analyses (phosphate, silicate, nitrate + nitrite, and nitrite) were performed on a modified 4-channel Technicon AutoAnalyzer, generally within a few hours after sample collection. Occasionally samples were refrigerated up to $6 \mathrm{~h}$ at $2-6^{\circ} \mathrm{C}$. All samples were brought to room temperature prior to analyses. Silicate was analyzed using the technique of Armstrong et al. (1967). A modification of the Armstrong 
et al. (1967) procedure was used for the analysis of nitrate and nitrite. Phosphate was determined using a modification of the Bernhardt and Wilhelms (1967) technique.

\subsubsection{Iodate/iodide}

Iodide was determined by cathodic square wave stripping analysis following the Luther et al. (1988) method with modifications following Tian and Nicolas (1995). A BASi electrode was used in CGME mode with the following procedures: $10 \mathrm{~mL}$ sample and $100 \mu \mathrm{L} 0.1 \%$ Triton, 5 min purge with oxygen-free nitrogen, $200 \mu \mathrm{L}$ addition of $1 \mathrm{M}$ sodium sulfite to remove any remaining oxygen, followed by $1 \mathrm{~min}$ of purging. The voltammogram was recorded three times under the following conditions: drop size 11, deposition time $90 \mathrm{~s}$, quiet time $5 \mathrm{~s}$, scan increment $2 \mathrm{mV}$, scan range $-120 \mathrm{mV}$ to $-700 \mathrm{mV}$, frequency $125 \mathrm{~Hz}$ and amplitude $25 \mathrm{mV}$. Precision was $1.9 \%$ RSD $(\mathrm{n}=10)$ and sensitivity $4.07 \mathrm{nA} / \mathrm{nM}$. Iodide concentrations were determined using the standard additions method of calibration for each sample.

Iodate was determined with the Wong and Brewer (1977) method using a spectrophotometer (Shimadzu $160 \mathrm{UV}$ ). In brief, a sample in a $10 \mathrm{~cm}$ quartz cuvette is acidified with sulfuric acid containing sulfanilamide to remove nitrite interference (Chapman and Liss, 1977; Rue et al., 1997) and excess iodide added to form tri-iodide that is then determined at a wavelength of $535 \mathrm{~nm}$. The standard additions method with iodate is used for daily calibration on a representative sample and its slope applied to subsequent samples. Duplicate samples were run for every depth and triplicate samples were determined for the 0 addition seawater to allow an estimate of precision for the rest of the samples.

\subsubsection{Arsenate/arsenite}

Arsenite and arsenate were determined using the selective hydride generation/gas chromatography with photoionization detection system of Cutter et al. (1991) on board ship. Arsine $\left(\mathrm{AsH}_{3}\right)$ is generated selectively from arsenite at $\mathrm{pH} 6.5$ (Tris-HCl buffer) using 4\% $\mathrm{NaBH}_{4}$ addition, stripped from solution with helium, cryotrapped, and then swept into the GC/PID for detection; peak areas are used and the detection limit is $10 \mathrm{pmol}^{-1}$. Acidifying another sample to $0.5 \mathrm{M} \mathrm{HCl}$ and generating and detecting arsine as before yields the concentration of As $(\mathrm{III}+\mathrm{V})$; arsenate is then the difference between this value and that of arsenite. For both determinations, precision was better than 5\% RSD for concentrations at and above $5 \mathrm{nmol} 1^{-1}$.

\subsubsection{Iron (II)}

Filled syringes (in batches of 2 or 3 ) were transferred from the sampling van to an adjacent analytical van and analyzed within $20 \mathrm{~min}$. Controls indicated the Fe(II) signal was stable under this treatment for at least $45 \mathrm{~min}$. Samples were ejected from the syringe into a $25 \mathrm{~mL}$ Teflon (FEP) bottle and entrained into the analytical system described below.

Dissolved Fe(II) concentrations were determined using the FeLume II system (Waterville Analytical) employing a luminol-based chemiluminescence reaction (King et al., 1995; Vedamati et al., 2014). The FeLume system was fitted with a standard quartz flow cell and a Hamamatsu HC135 photon counter configured with the following settings: pump speed: 15 revolutions per minute (rpm); photon counter integration time: 200 milliseconds; load time: $20 \mathrm{~s}$.

In the FeLume system, luminol, buffered to $\sim \mathrm{pH} 10.3$ with ammonia, reacts with an $\mathrm{Fe}(\mathrm{II})$-containing solution, resulting in luminol oxidation with concurrent chemiluminescent emission (Rose and Waite, 2001; Croot and Laan, 2002). The mixing and reaction takes place in a spiral flow cell positioned in front of a photomultiplier tube. The sample and luminol reagent are continually mixed in the flow cell by omitting the injection valve (Rose and Waite, 2001; Hopkinson and Barbeau, 2007; Roy et al., 2008). Lab View software (National Instruments) controls the loading and injection of the sample and luminol into the flow cell, while the intensity of the luminescence is recorded as the sample passes through the reaction coil. The quantification of the signal is done by measuring the height of the signal peak averaged over $20 \mathrm{~s}$ at five counts per second. On this cruise, detection limits were determined for surface samples where ferrous iron was negligible based on a standard $3 \sigma$ evaluation of the baseline signal (Kondo and Moffett, 2015; Moffett et al., 2007); this led to a detection limit of $14 \mathrm{pmol}$ $1^{-1}$.From Vedamati et al. (2014), the standard error is $\pm 5 \%$ for Fe(II) data below $5 \mathrm{nmol}^{-1}$ (comprising all the data determined in this study).

\subsubsection{Sulfate/sulfide}

The determination of total hydrogen sulfide (free + complexed) is done on board ship within $2 \mathrm{~h}$ of sample collection and uses acidification, gas stripping and cryogenic trapping/preconcentration, and gas chromatography/flame photometric detection (Radford-Knoery and Cutter, 1993). The system is calibrated with hydrogen sulfide from a permeation tube with calibrated diffusion rate, and for a $50 \mathrm{~mL}$ sample the detection limit was $60 \mathrm{pmol}^{-1}$.

\section{Results}

In the redox sequence of potential terminal electron acceptors for respiration depicted in Fig. 1 and considered in this paper, the reduced products going from most to least oxidized include, but are not limited to, water, iodide, nitrite, arsenite, Fe(II), and hydrogen sulfide. Oxygen concentrations obtained along the transect showed that the suboxic zone where oxygen concentrations were $<2 \mu \mathrm{mol} 1^{-1}$ (method detection limits), were in the upper $1000 \mathrm{~m}$ and extended from the innermost shelf at Station 2 to offshore Station 13 (Fig. 3). Iodide (Fig. 4a) in the upper $1000 \mathrm{~m}$ was detectable along the entire transect and while most concentrated in the suboxic zone, could also be observed in the fully oxygenated water column. This is consistent with previous studies that demonstrated iodide production by phytoplankton during active photosynthesis (e.g., Wong et al., 2002). Similarly, nitrite was highest in suboxic waters, but the primary nitrite maximum was above the

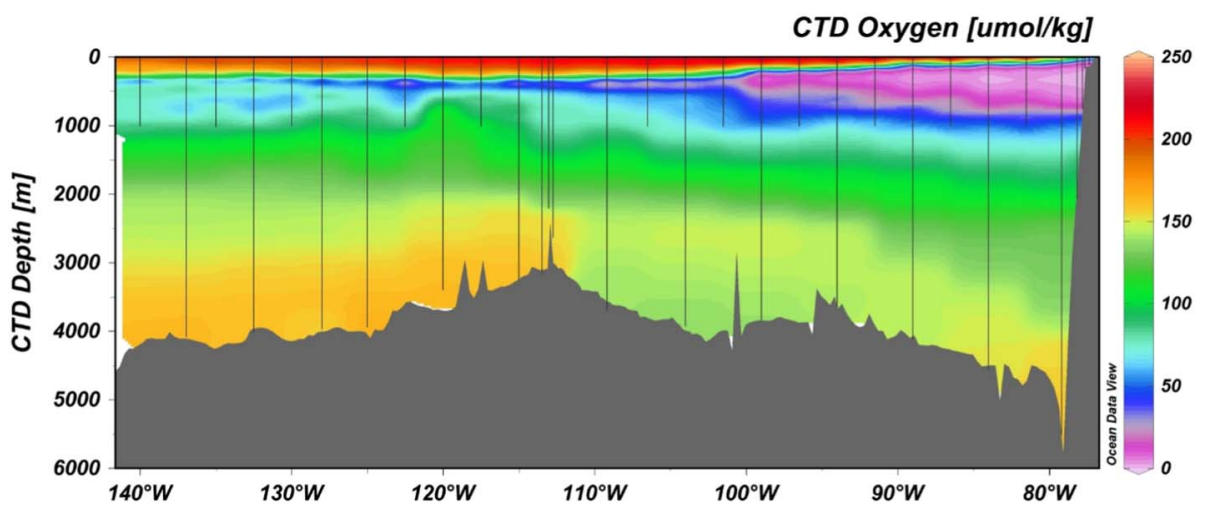

Fig. 3. Oxygen concentrations along the US GEOTRACES cruise GP16 transect (refer to Fig. 2). 

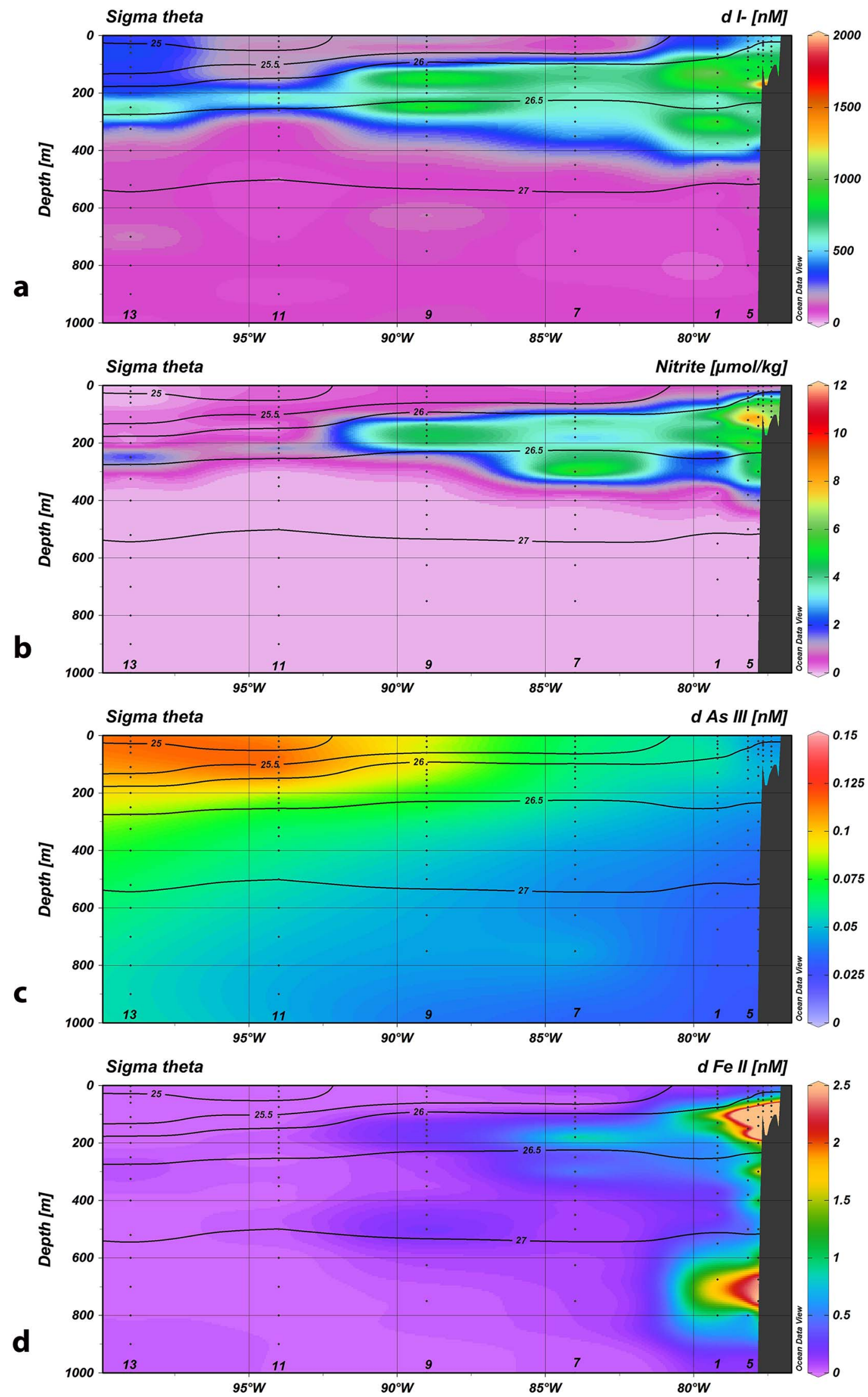

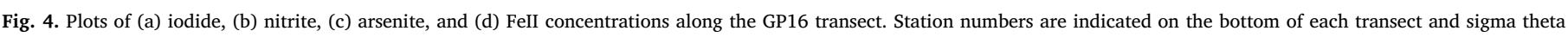
densities are overlaid in each plot. 
suboxic layer, within the oxycline (Fig. 4b). Arsenite is also produced by phytoplankton uptake and reduction, but this process has been linked with detoxification depending on the ambient concentrations of phosphate (Wurl et al., 2013), in addition to reduction within suboxic waters (e.g., Cutter, 1991). However, there is no arsenite increase within the suboxic zone (Fig. 4c).

Dissolved Fe(II) distributions are shown in Fig. 4d. Concentrations were exceedingly high on the shelf, decreased offshore and narrowed to a feature at the top of the OMZ spanning the potential density $\left(\sigma_{\theta, 0}\right)$ range 26.1 to $26.6 \mathrm{~kg} \mathrm{~m}^{-3}$. This feature was approximately coincident with the secondary nitrite maximum (SNM) and extended as far as Station 11. These observations are in general agreement with measurements made in 2005 (Vedamati et al., 2014) and 2010 (Kondo and Moffett, 2015). Fe(II) concentrations decreased rapidly below the SNM, similar to iodide. These co-occurring maxima suggest that there are similar controls acting on both species. Elevated Fe(II) was also observed at the base of the ODZ at Stations 1 and 5. These were the stations closest to the slope at that depth horizon. Iodide was not elevated at this depth, and we suspect a lateral source of Fe from the slope may have contributed to this feature.

Dissolved hydrogen sulfide was undetectable at $<60 \mathrm{pmol}^{-1}$ along the entire transect at all depths. This is at odds with earlier reports of hydrogen sulfide in the Peru and Chile margin water column (Schunck et al., 2013), but those observations were thought to be associated with an episodic event.

Nitrate reduction associated with denitrification (Codispoti et al., 2005 ) is quantified by comparing the observed nitrate with the predicted nitrate computed from the observed phosphate divided by the Redfield ratio (canonically 16:1 but adjusted for empirical observations from deep waters along the offshore Stations 15-36 on GP16, so Predicted $\left.\left.\left[\mathrm{NO}_{3}{ }^{-}\right]=\left(\left[\mathrm{PO}_{4}{ }^{3-}\right]-0.1\right) \times 14.3\right) ; \mathrm{r}^{2}=0.99\right)$. These two parameters, and nitrite, for Stations $3,5,9,11$, and 13 are shown in Figs. 5-9. These depth profiles show the difference between predicted and observed nitrate, the nitrate deficit, and nitrite frequently have two maxima (e.g., Stn. 5, Fig. 6) and even when there is only one maximum, its depth varies by station. However, plotting all of the OMZ data onto density surfaces facilitates station by station comparisons. In Fig. 10, the greatest nitrate deficit is centered on $\sigma_{\theta, 0}=26.3 \mathrm{~kg} \mathrm{~m}^{-3}$, with a lesser deficit at ca. $\sigma_{\theta, 0}=25.6 \mathrm{~kg} \mathrm{~m}^{-3}$. Since these data are plotted by station, it is also apparent that there is no definitive on-shore/off-shore trend, implying nitrate reduction is largely occurring in situ rather than being transported along the $\sigma_{\theta, 0}=26.3 \mathrm{~kg} \mathrm{~m}^{-3}$ isopycnal.

\section{Discussion}

Chemical species associated with six redox couples were measured in this study. Which one controls the $\mathrm{p} \varepsilon$ ? The presence of any oxygen would imply that it controls the pe, even if poised at concentrations around our micromolar detection limits. As noted previously, methods with much lower detection limits than those used here demonstrate that the oxygen levels in this region are likely in the nanomolar range. (Revsbech et al., 2009; Tiano et al., 2014). As a result, we can assume the $\mathrm{p} \varepsilon$ is more likely controlled by the nitrate/nitrite couple (Fig. 1). However, the redox couple that should be closely paralleling nitrate reduction is iodate/iodide as observed in eastern tropical North Pacific suboxic zone (Rue et al., 1997) where complete iodate reduction was matched by quantitative iodide production. However, in the suboxic zone sampled during GP16 no station showed complete iodate reduction, but concentrations of iodide were as high or higher than those of iodate (Figs. 5-9). The actual amount of iodate depletion was calculated in a fashion similar to that of nitrate: observed phosphate concentrations were used to predict iodate concentrations using the previously observed correlation between the two (Wong and Brewer, 1974), but recalibrated using deep water data from Stations 7-13 below the suboxic zone (Predicted $\left.\left[\mathrm{IO}_{3}{ }^{-}\right]=\left(\left[\mathrm{PO}_{4}{ }^{3-}\right] \times 0.103\right)+179, \mathrm{r}^{2}=0.53\right)$; these predictions are also plotted on Figs. 5-9.

While not completely reduced, there is measurable iodate depletion and the difference between predicted and observed, the iodate deficit, was relatively similar at every station within the suboxic interval, 100-200 nmol $1^{-1}$ (Figs. 5-9). Like the nitrate deficit, this suggests in situ reduction, but unlike earlier observations off Mexico (Rue et al., 1997), the observed concentrations of iodide ( $\left.>400 \mathrm{nmol} \mathrm{l}^{-1}\right)$ are

\section{Station 3}
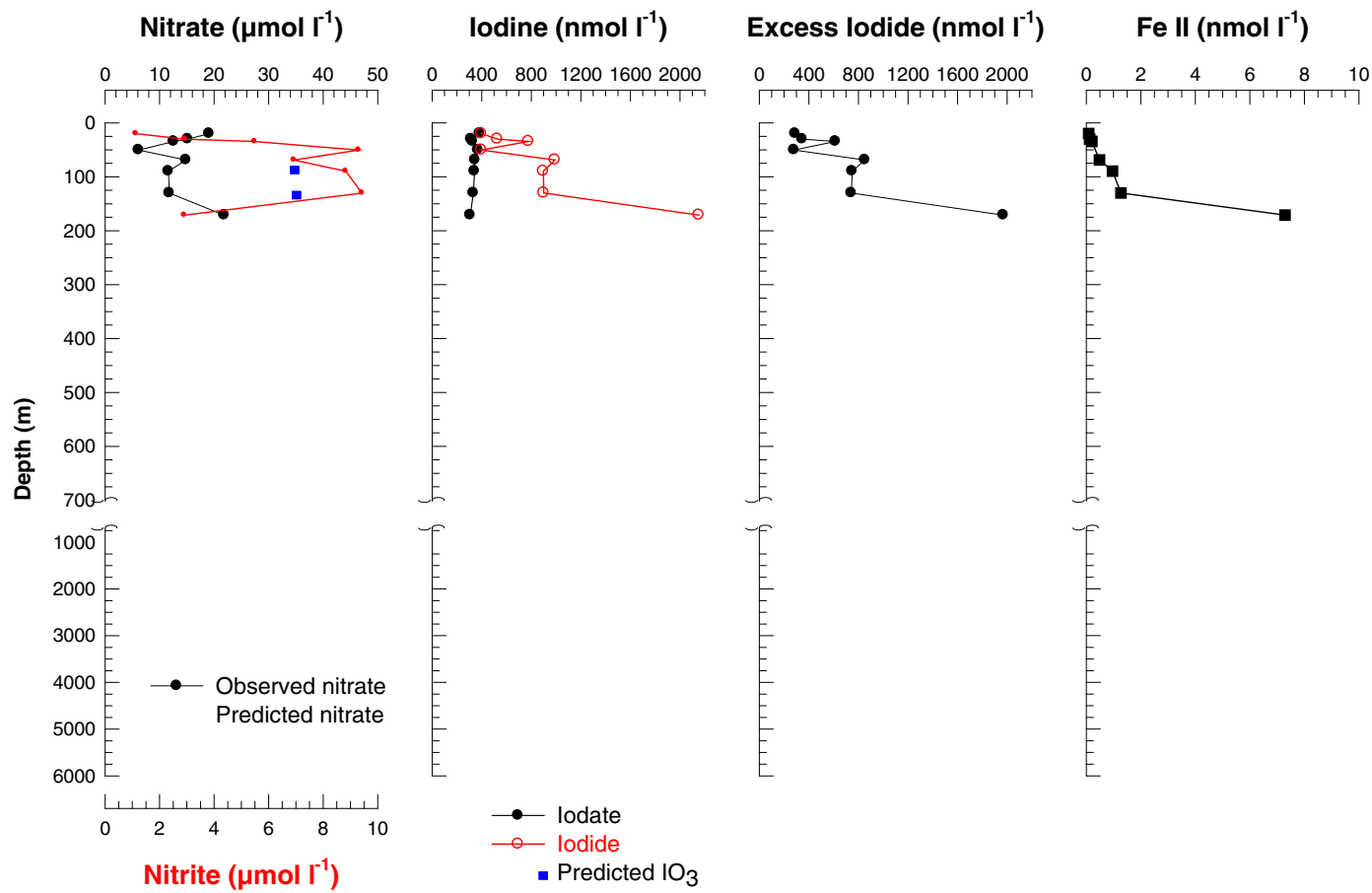

Fig. 5. Depth profiles of nitrate, predicted nitrate, nitrite, iodate, predicted iodate, iodide, excess iodide, and Fe(II) at shelf Station 3 . Note depth scale break at $700 \mathrm{~m}$. 


\section{Station 5}

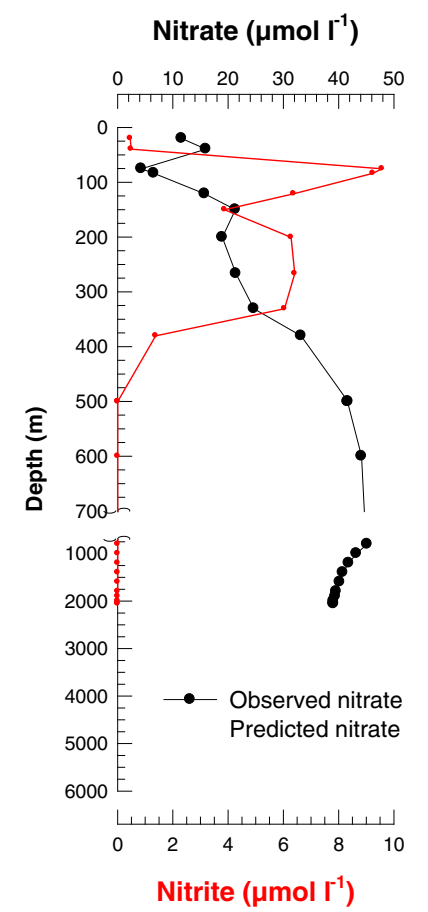

\section{lodine $\left.(\mathrm{nmol} \mathrm{I})^{-1}\right) \quad$ Excess lodide $\left(\mathrm{nmol} \mathrm{I}{ }^{-1}\right)$}

Fe II (nmol I $\left.{ }^{-1}\right)$
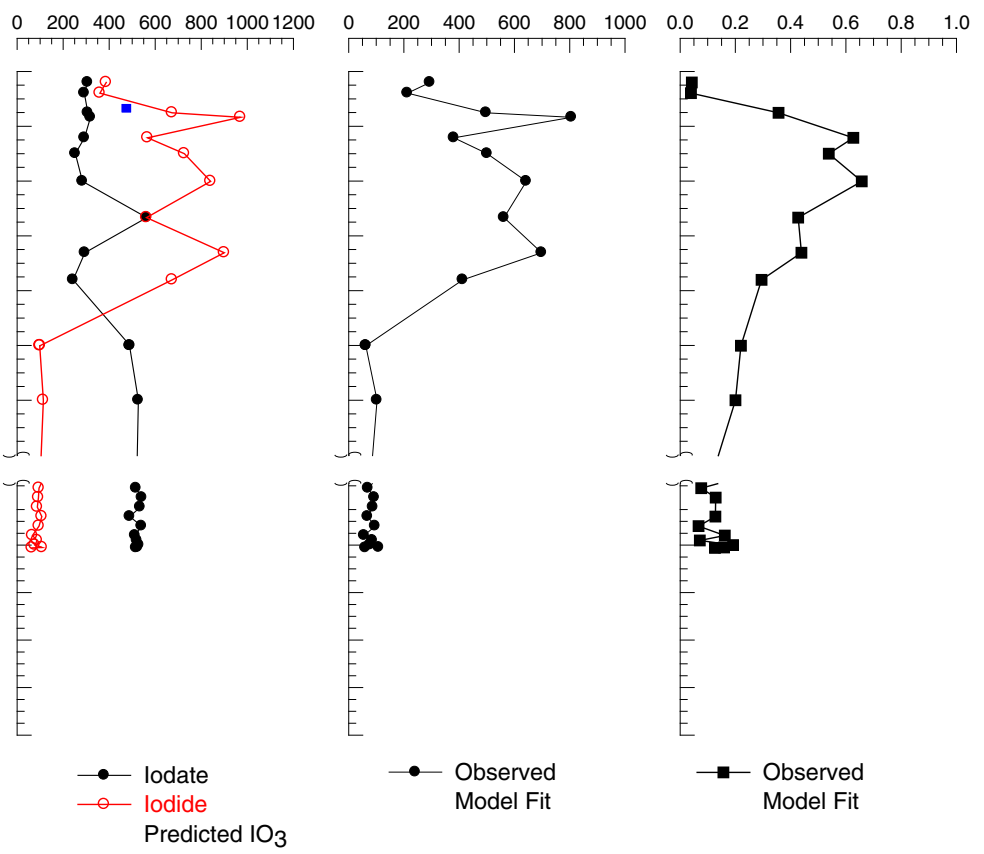

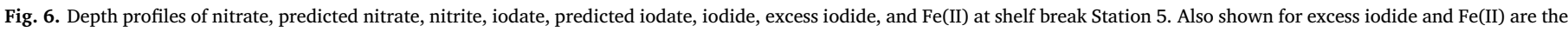
1-D advection/diffusion model fit to the observed data that is described in the Discussion. Note depth scale break at $700 \mathrm{~m}$.

much higher than the deficit $\left(100-200 \mathrm{nmol} \mathrm{l}^{-1}\right)$, therefore they cannot be explained by in situ reduction. Similarly high iodide concentrations were found in the suboxic Arabian Sea $(950 \mathrm{nmol} / \mathrm{L}$; Farrenkopf and Luther, 2002), although iodate was completely depleted. To quantify this 'excess' iodide in the equatorial Pacific, the calculated iodate deficit that should produce a stoichiometric amount of iodide was subtracted from the observed iodide, with the error in excess iodide largely driven by the error in predicted iodate (as above,

\section{Station 9}

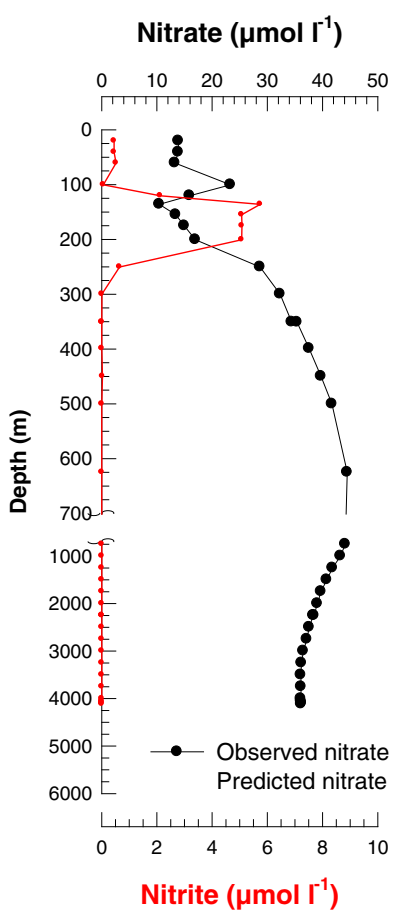

\section{lodine (nmol I $\left.{ }^{-1}\right)$}

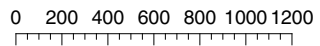
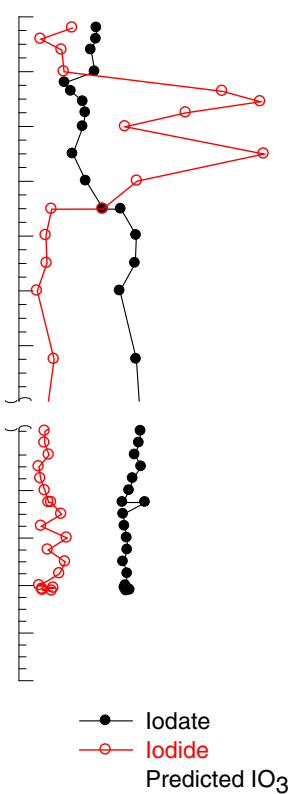

Excess lodide $\left(\mathrm{nmol} \mathrm{I}^{-1}\right)$

Fe II (nmol I')
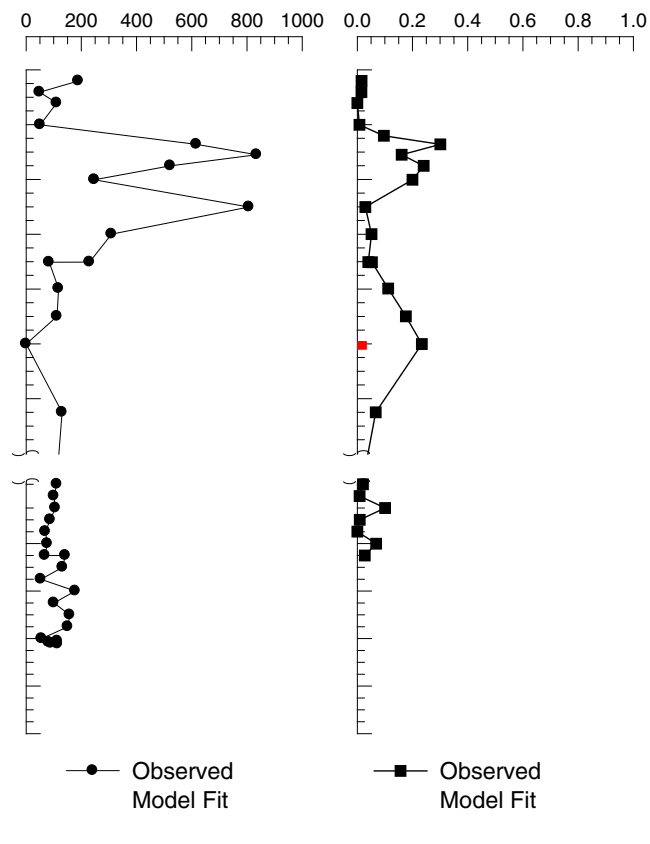
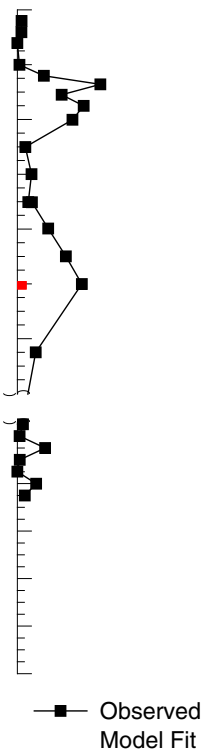

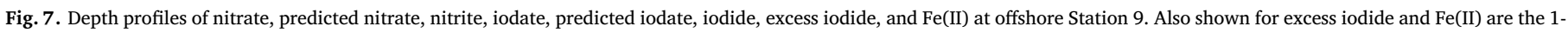
$\mathrm{D}$ advection/diffusion model fit to the observed data that is described in the Discussion. Note depth scale break at $700 \mathrm{~m}$. 
Station 11

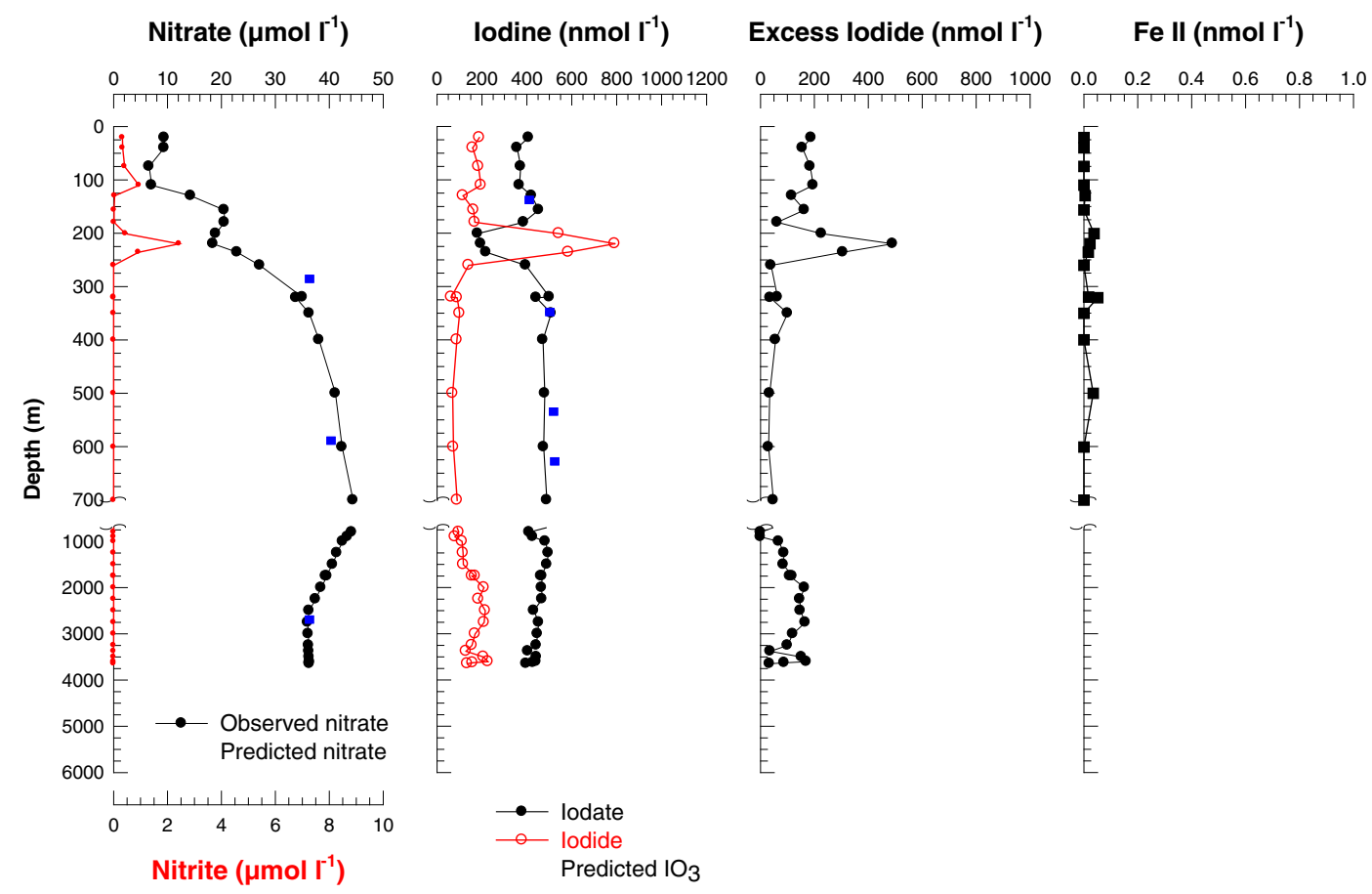

Fig. 8. Depth profiles of nitrate, predicted nitrate, nitrite, iodate, predicted iodate, iodide, excess iodide, and Fe(II) at offshore Station 11 . Note depth scale break at $700 \mathrm{~m}$.

the $r^{2}=0.53$ yields an up to $23 \%$ error); the depth profiles of this excess iodide are plotted in Figs. 5-9. In surface waters, there is excess iodide of up to $100 \mathrm{nmol} / \mathrm{L}$ likely produced during photosynthesis as reported by numerous workers (e.g., Wong et al., 2002). However, the bulk of excess iodide is within the suboxic zone. Farrenkopf and Luther (2002) argued that the excess iodide in the Arabian Sea OMZ was from sediment fluxes, using the pore water data of Passier et al. (1997) to support their argument, but no direct measurements were made. Interestingly, the highest excess iodide during GP16 was found $2 \mathrm{~m}$ above the sediment/water interface of Station 3 (Fig. 5). Plotting excess iodide versus density (Fig. 11) shows that the maximum of excess iodide was centered on the $26.5 \mathrm{~kg} \mathrm{~m}^{-3}$ isopycnal and generally decreased moving

\section{Station 13}

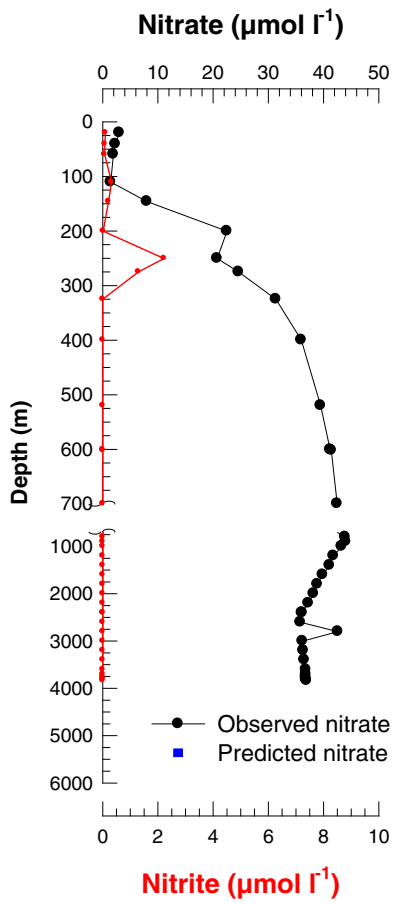

lodine $\left(\mathrm{nmol} \mathrm{^{-1 }}\right)$

$0 \quad 200400600 \quad 80010001200$
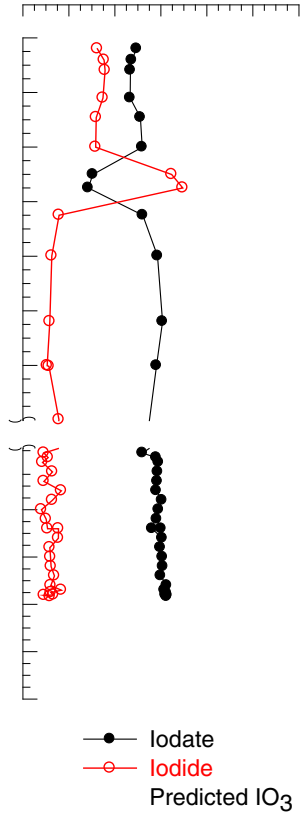

Excess lodide $\left.(\mathrm{nmol} \mathrm{I})^{-1}\right)$

Fe II (nmol I $\left.{ }^{-1}\right)$
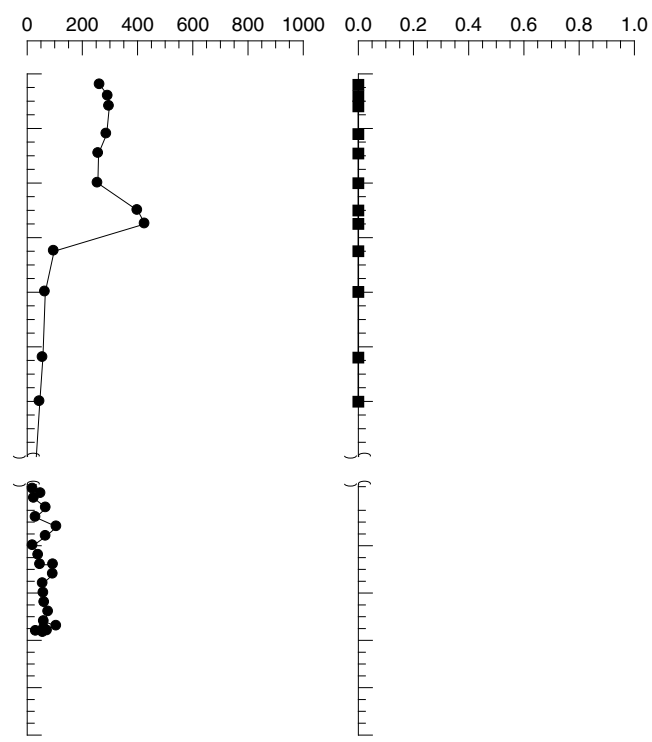

Fig. 9. Depth profiles of nitrate, predicted nitrate, nitrite, iodate, predicted iodate, iodide, excess iodide, and Fe(II) at offshore Station 13 . Note depth scale break at $700 \mathrm{~m}$. 


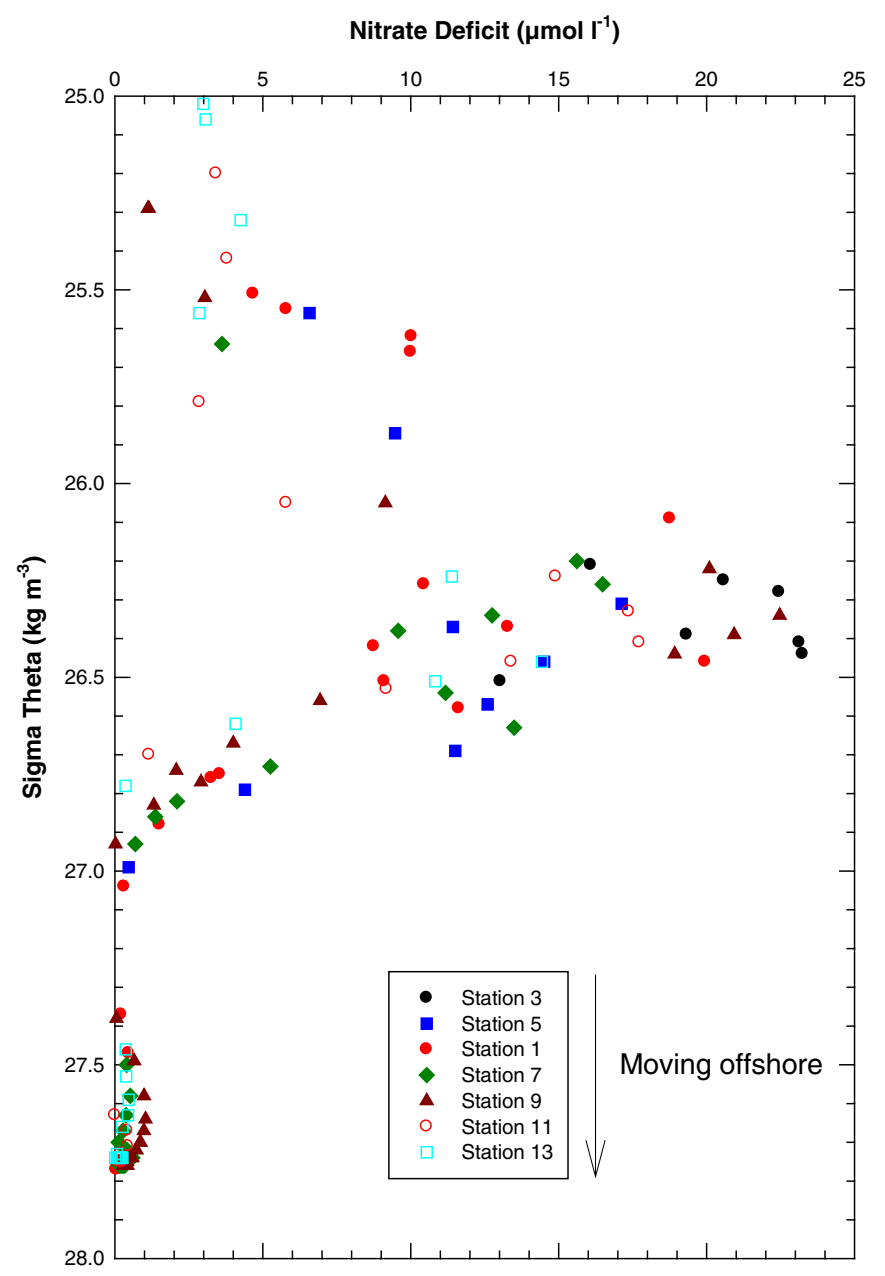

Fig. 10. Nitrate deficit as a function of density along the offshore transect, with Station 3 the most inshore station and Station 13 being the farthest offshore.

offshore, implying a shelf sediment source. However, it is also important to remember that this source is regional and not necessarily the shelf stations occupied by this cruise.

Considering the redox data within the suboxic zone examined so far - the lack of hydrogen sulfide, no apparent arsenate reduction, incomplete iodate reduction, and apparent control by the nitrite/nitrate couple - it seems that this oxygen minimum zone had a p $\varepsilon$ in the range of 5-10, much too high to allow in situ Fe(III) reduction. What processes might be occurring that enable Fe(II), but not sulfide or As(III) to accumulate? In addressing this question, there are two critical observations to consider. First, there is a large benthic source of $\mathrm{Fe}(\mathrm{II})$ on the shelf that presumably arises from sediment pore waters where nitrate has already been eliminated, thus production is consistent with thermodynamics (e.g., Noffke et al., 2012; Scholz et al., 2014). Second, the observed $\mathrm{Fe}(\mathrm{II})$ at offshore stations is restricted to a narrow density window, $\sigma_{\theta, 0}=26.1$ to $26.6 \mathrm{~kg} \mathrm{~m}^{-3}$ (Fig. 12). This window is also the same density range as the elevated Fe(II) feature on the Peruvian shelf (Fig. 4d). Therefore, one explanation is lateral advection/diffusion from the shelf, coupled with oxidation that is slow enough to enable offshore transport, but fast enough to prevent diapycnal mixing of $\mathrm{Fe}(\mathrm{II})$ to deeper waters within the OMZ. A reducing sediment source seems to be the best explanation given high Fe(II) fluxes reported by others (e.g., Noffke et al., 2012). Indeed, plotting Fe(II) against density for all stations (Fig. 12) shows that like excess iodide, Fe(II) is centered on the $26.5 \mathrm{~kg} \mathrm{~m}^{-3}$ isopycnal, and displays an even stronger decreasing concentration with distance offshore. It should also be noted that for iodide

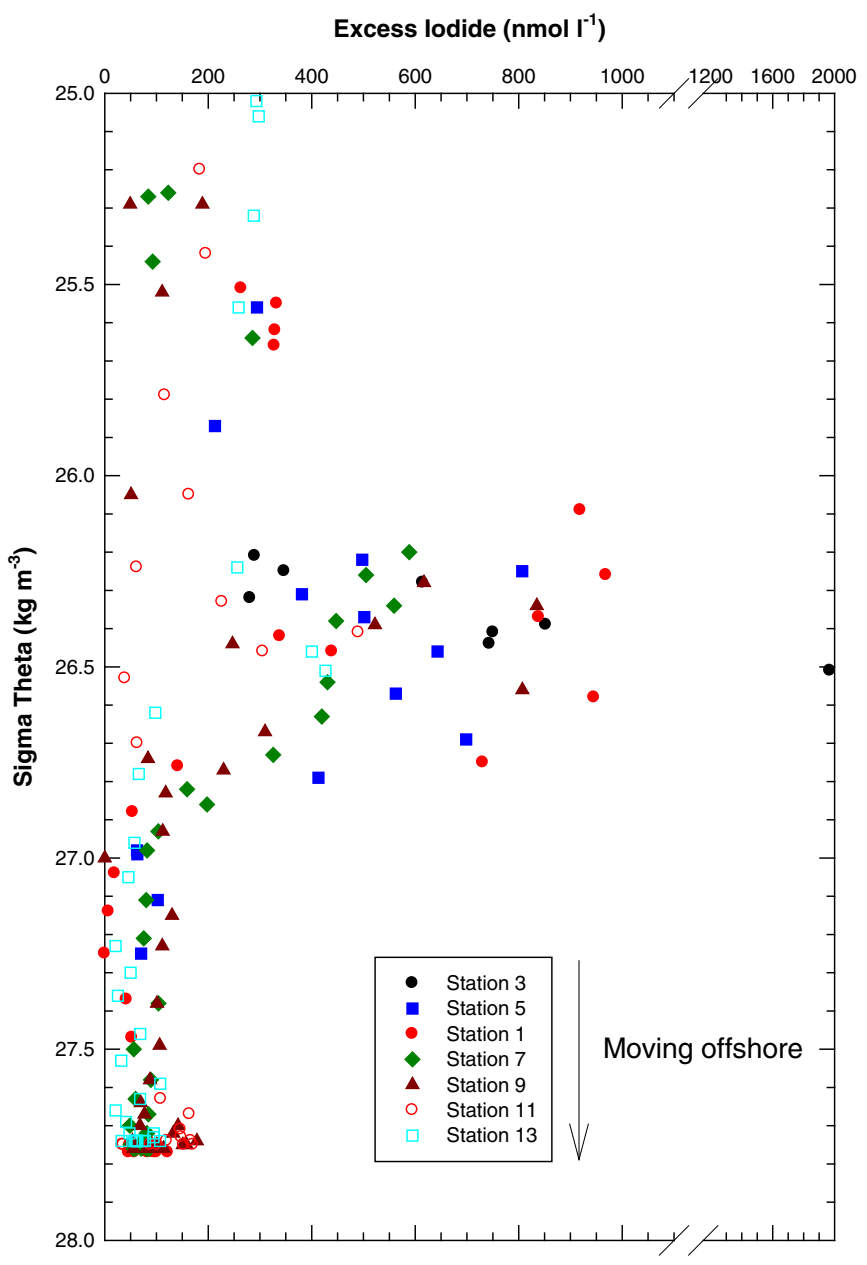

Fig. 11. Computed excess iodide as a function of density along the offshore transect, with Station 3 the most inshore station and Station 13 being the farthest offshore. Note the concentration scale break.

and $\mathrm{Fe}(\mathrm{II})$, the data are centered slightly deeper than for the nitrate deficit in Fig. $10\left(\sigma_{\theta, 0}=26.5\right.$ versus 26.3$)$. This probably reflects the importance of benthic sources, near $\sigma_{\theta, 0}=26.5$, which is especially apparent for Fe(II) in Fig. 12. Further offshore, these differences are less apparent.

Having acknowledged a potential shelf sediment source for Fe(II) and excess iodide, it should be noted that the density range $\sigma_{\theta, 0}=26.1$ to $26.6 \mathrm{~kg} \mathrm{~m}^{-3}$ is also associated with the secondary nitrite maximum (SNM; Fig. 4b) and a maximum in particle concentration (from transmissometry, data not shown). In OMZs, the SNM and associated particle maximum is an area of high microbial activity and biomass (Naqvi and Shailaja, 1993), which suggests that in situ microbial processes may play a role. Mechanisms could include the development of highly reducing regimes in sinking particles undergoing denitrification-mediated regeneration, perhaps including non-dissimilatory Fe(III) reduction, for example by anammox (van de Vossenberg et al., 2008) or cryptic sulfate reduction (Canfield et al., 2010). Examining the profiles for Fe(II) and of particulate acid volatile sulfide (i.e., $\mathrm{CdS}+\mathrm{FeS}+\mathrm{NiS}+\mathrm{ZnS}$; Radford-Knoery and Cutter, 1993) that are reported in Ohnemus et al. (2016), the maxima in both properties coincides offshore at Stations 9 and 11. Assuming particulate acid-volatile sulfide (pAVS) is a proxy for dissimilatory sulfate reduction within particles (e.g., cryptic sulfur cycle of Canfield et al., 2010), then this could be a source of Fe(II) offshore. However, it still requires another source at the stations proximal to the coast. The large suite of tracers gathered on the GP16 cruise enable us 
Fe II (nmol I $\left.{ }^{-1}\right)$

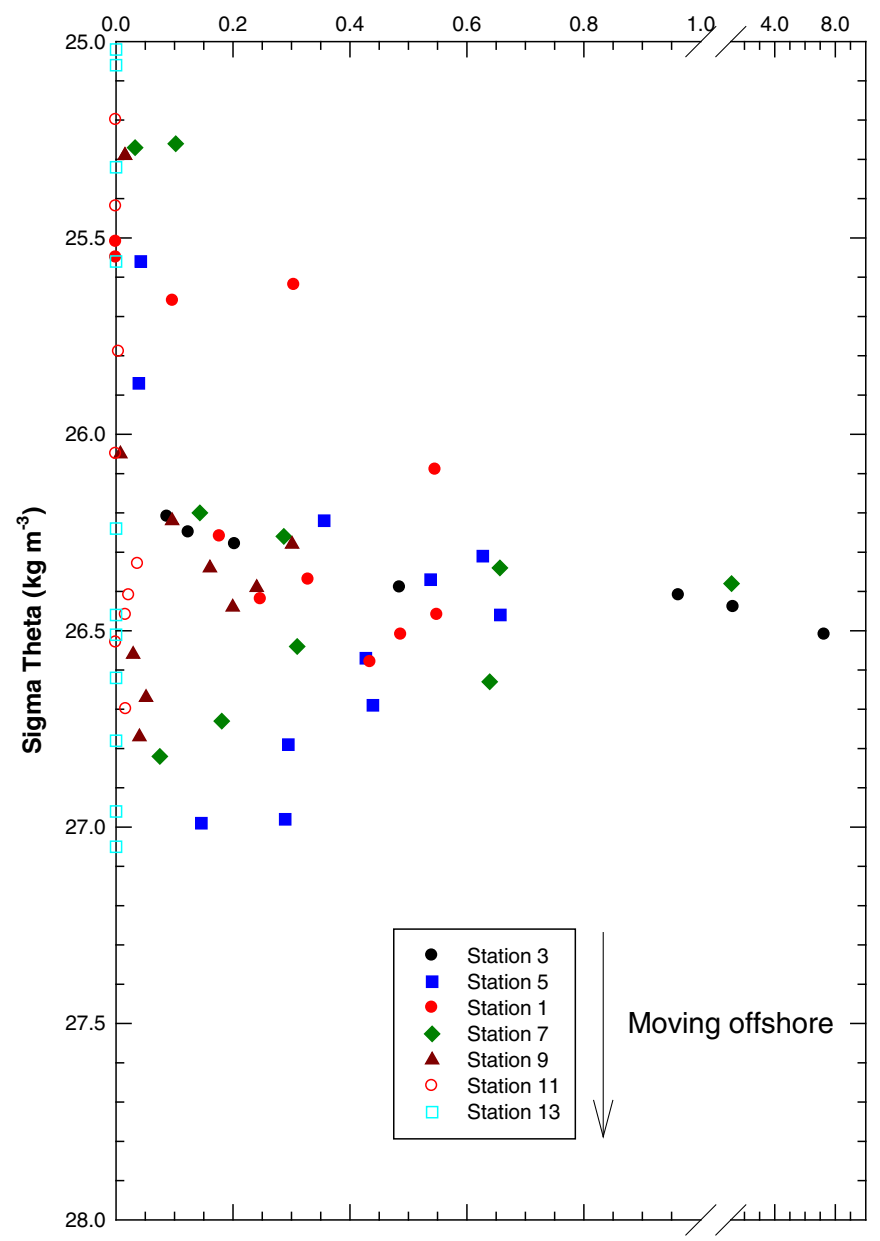

Fig. 12. Observed Fe(II) as a function of density along the offshore transect, with Station 3 the most inshore station and Station 13 being the farthest offshore. Note the concentration scale break.

to evaluate the most important processes that account for the redox behaviors reported here. This we have done, beginning with arguably the most plausible source, the Peruvian shelf.

Measurements of ${ }^{228} \mathrm{Ra}$ on the same cruise provide an independent approach to quantifying boundary (sediment) sources of Fe(II) and excess iodide. Recently, Sanial et al. (n.d.) determined the coastal fluxes of dissolved Co, Mn, and Fe based on ${ }^{228} \mathrm{Ra}$ off the continental Peruvian margin. Using the approach described in Charette et al. (2016), Sanial et al. (n.d.) combined this radium flux with the trends observed in metal concentrations versus ${ }^{228} \mathrm{Ra}$ to derive shelf and slope fluxes of a variety of metals, including dissolved Fe. A similar approach was used here, but because the sampling resolution of ${ }^{228} \mathrm{Ra}$ measurements were much lower than those of Fe(II) and excess iodide, we computed depth-integrated averages for these species for comparisons; these are then used to estimate the $\mathrm{Fe}(\mathrm{II}) /{ }^{228} \mathrm{Ra}$ and excess iodide $/{ }^{228} \mathrm{Ra}$ ratios (Fig. 13a and b). Focusing exclusively on ${ }^{228} \mathrm{Ra}$ and $\mathrm{Fe}(\mathrm{II})$ within the density range $\sigma_{\theta, 0}=26.1$ to $26.6 \mathrm{~kg} \mathrm{~m}^{-3}$ we observed a linear relationship for $\mathrm{Fe}(\mathrm{II})$ versus ${ }^{228} \mathrm{Ra}$ (Fig. 13a).

In order to determine the $\mathrm{Fe}(\mathrm{II})$ flux, which is primarily between 26 and $26.6 \mathrm{~kg} \mathrm{~m}^{-3}$, we first determined the fraction of the shelf area assumed to be the source of ${ }^{228} \mathrm{Ra}$ in Sanial et al. (n.d.) that intersects with this density interval; this fraction was approximately $91 \%$. Thus, we estimated that the Ra flux in the density range $26.1-26.6 \mathrm{~kg} \mathrm{~m}^{-3}$ is
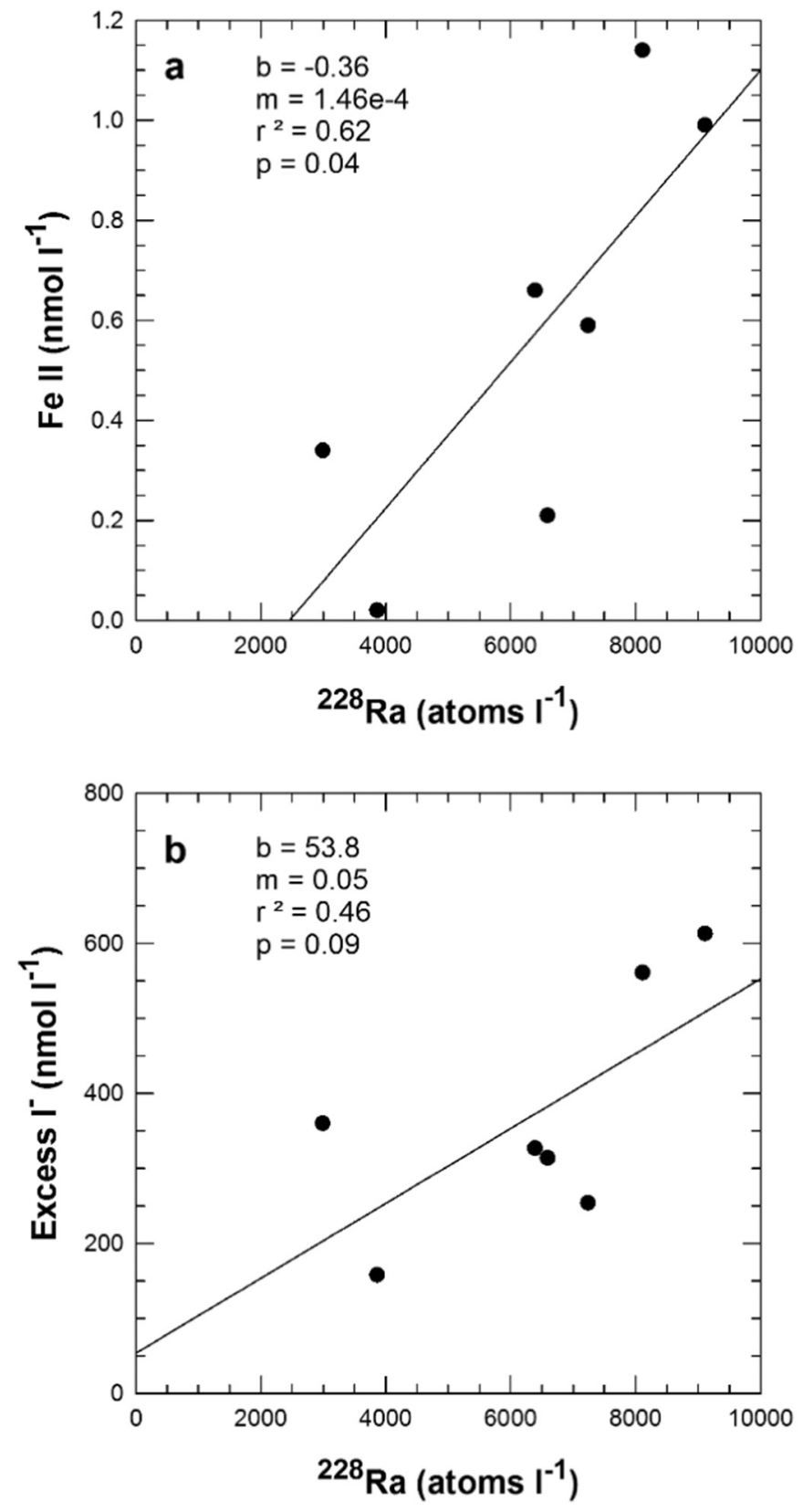

Fig. 13. Relationships between sediment-derived ${ }^{228} \mathrm{Ra}$ and (a) Fe(II) and (b) excess iodide. All three parameters are the depth-integrated averages at Stations 1, 3, 5, 7, 9 and 11 for densities between 26.0 and $26.6 \mathrm{~kg} \mathrm{~m}^{-3}$. Linear fit statistics are given within the figures.

Table 1

Comparisons of apparent 1-dimensonal advection/diffusion rates in the suboxic water column with those from the shelf/margin (fluxes in $\mathrm{mol} \mathrm{d}^{-1}$ ).

\begin{tabular}{lll}
\hline Parameter & 1-D Model & ${ }^{228}$ Ra-derived fluxes from margin \\
\hline Fe(II) & $3.3 \pm 0.4 \times 10^{4}$ & $2.3 \pm 0.8 \times 10^{5}$ \\
Excess I $^{-}$ & $8.6 \pm 1.8 \times 10^{7}$ & $7.5 \pm 3.0 \times 10^{7}$ \\
\hline
\end{tabular}

$91 \%$ of $1.6 \times 10^{18}$ atoms $d^{-1}=1.5 \times 10^{18}$ atoms $d^{-1}$ Sanial et al., n.d.. Considering that the shelf-ocean exchange is primarily driven by horizontal eddy diffusion, the Fe(II) flux was then derived as follows: 
$\mathrm{Fe}(\mathrm{II})$ flux $=$ Ra Flux $* \mathrm{Fe}(\mathrm{II}) / \mathrm{Ra}$ ratio (From the slope in Fig. 13a) $=1.5 \times 10^{18}$ atoms $\mathrm{d}^{-1 *} 1.5 \pm 0.5 \times 10^{-4} \mathrm{nmol}_{\text {atoms }}{ }^{-1}$ $=2.3 \pm 0.8 \times 10^{5} \mathrm{~mol} \mathrm{~d}^{-1}$

This ${ }^{228}$ Ra-derived offshore flux of Fe(II) (Table 1) is about $50 \%$ of the estimate of total dissolved Fe coming off the shelf reported in Sanial et al. (n.d.), suggesting that both Fe(II) and Fe(III) are transported offshore in a similar manner. However, it is also important to note the potential errors ( $\pm 33 \%$ for $\mathrm{Fe}(\mathrm{II}):{ }^{228} \mathrm{Ra}$ ratio) and assumption that $\mathrm{Fe}$ (II) is derived from sediment fluxes and not produced in the water column. In the same manner as Fe(II), the shelf sediment flux for excess iodide was calculated using the observed excess iodide $/{ }^{228} \mathrm{Ra}$ ratio of $0.05 \pm 0.02 \mathrm{nmol}$ atom $^{-1}$ (Fig. 13b) times the ${ }^{228} \mathrm{Ra}$ flux, resulting in a shelf flux for excess iodide of $7.5 \pm 3.0 \times 10^{7} \mathrm{~mol} \mathrm{~d}^{-1}$ (Table 1). Again, the error in this flux is largely driven by the error in the excess iodide $/{ }^{228} \mathrm{Ra}$ ratio.

The ${ }^{228} \mathrm{Ra}$ approach provides quantifiable evidence of $\mathrm{Fe}(\mathrm{II})$ and excess iodide fluxes coming from the coastal/shelf sediments into the offshore suboxic waters, but are they sufficient to explain the observed water column behavior? One approach is to estimate the rates of vertical mixing processes that would eliminate these features, which can then be compared with the ${ }^{228}$ Ra-derived fluxes. A straightforward approach is the traditional one dimensional, advection/diffusion (A/D) modeling originally described by Craig (1969) and applied to systems such as the Black Sea (Spencer and Brewer, 1971; Cutter, 1991). This approach assumes a simple two end-member mixing with no horizontal inputs. Thus, it cannot explain the observed maxima - its value comes from the limits it places on the importance of the ${ }^{228}$ Ra-derived fluxes. The model is applicable when spanning a region with a linear relationship in potential temperature-salinity plots. A linear T-S region at Station 5 covers almost all of the suboxic zone (68-555 m), while $2 / 3$ of suboxic region at Station 9 was included (144-568 m) (from data available at www.bco-dmo.org/dataset/522646). Significantly, these two stations also bracket $80 \%$ of the offshore extent of the suboxic waters with $\mathrm{Fe}(\mathrm{II})$ and excess iodide (Fig. 4). A major shortcoming of the approach is that generic assumptions are often made about vertical eddy diffusivity and upwelling in the absence of real data. However, on this cruise Kadko (2017) computed the upwelling rates (0-3 $\mathrm{m} \mathrm{d}^{-1}$; highest at the shelf break and lowest offshore) and vertical eddy diffusivity $\left(\mathrm{K}_{\mathrm{z}} ; 1.7-4.5 \times 10^{-4} \mathrm{~m}^{2} \mathrm{~s}^{-1}\right)$ at stations along the transect from ${ }^{7} \mathrm{Be}$ data. These values were used in the Craig (1969) solution to the stable but non-conservative $\mathrm{A} / \mathrm{D}$ equation:

$$
\begin{aligned}
\mathrm{C}_{\mathrm{z}}= & \mathrm{C}_{0}+\left(\mathrm{C}_{\mathrm{m}}-\mathrm{C}_{0}\right) \times\left(\mathrm{e}^{\mathrm{z} / \mathrm{z}^{*}}-1\right) /\left(\mathrm{e}^{\mathrm{zm} / \mathrm{z}^{*}}-1\right) \\
& +(\mathrm{J} / \mathrm{w}) \times\left(\mathrm{e}^{\mathrm{z} / \mathrm{z}^{*}}-1\right) /\left(\mathrm{e}^{\mathrm{zm} / \mathrm{z}^{*}}-1\right)
\end{aligned}
$$

where $\mathrm{C}_{\mathrm{z}}$ is the concentration at any depth $\mathrm{z} ; \mathrm{C}_{\mathrm{m}}$ is the concentration at the upper depth; $\mathrm{C}_{0}$ is the concentration at the lower depth; $\mathrm{z}$ is depth; $\mathrm{zm}$ is the upper depth; $\mathrm{z}^{*}$ is $\mathrm{K}_{\mathrm{z}}$, the vertical eddy diffusion coefficient (from Kadko, 2017) divided by the $\mathrm{w}$, upwelling rate ( $\mathrm{m} \mathrm{d}^{-1}$; Kadko, 2017); and $\mathrm{J}$ is the constant production/consumption rate (nmoles $1^{-1} \mathrm{~d}^{-1}$ ) that is the key parameter we seek. The equation was fitted to the observed Fe(II) and calculated excess iodide data to obtain a constant (not exponentially decreasing) $\mathrm{J}$ term - the apparent in situ production/consumption rates in the OMZ.

The model fits to the data are shown in Fig. 6 for Station 5 and Fig. 7 for Station 9. For $\mathrm{Fe}(\mathrm{II})$ the model predicts a production rate of $4.8 \pm 0.4 \times 10^{-4} \mathrm{nmol} \mathrm{Fe} 1^{-1} \mathrm{~d}^{-1}\left(\mathrm{r}^{2}=0.86\right)$ to maintain the observed Fe(II) maximum over the $425 \mathrm{~m}$ OMZ interval at Station 5 and $0.8 \pm 0.4 \times 10^{-4} \mathrm{nmol} \mathrm{Fe} \mathrm{l}^{-1} \mathrm{~d}^{-1}\left(\mathrm{r}^{2}=0.84\right)$ over the $489 \mathrm{~m}$ depth range at Station 9's OMZ. The equivalent modeling for excess iodide, which should be remembered is a calculated parameter and therefore

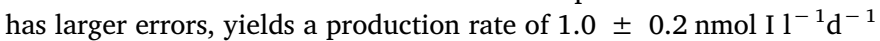
$\left(\mathrm{r}^{2}=0.59\right)$ to maintain the calculated excess iodide maximum at Station 5's $425 \mathrm{~m}$ modeled OMZ and $0.4 \pm 0.2 \mathrm{nmol} \mathrm{I}^{-1} \mathrm{~d}^{-1}\left(\mathrm{r}^{2}=0.52\right)$ at Station 9's $489 \mathrm{~m}$ OMZ. The fact that the required production rates for both Fe(II) and excess iodide at Station 9 are less than half those at
Station 5 is consistent with its location being farther offshore and more distant from a presumed sediment source (i.e., Figs. 11 and 12).

The shelf fluxes of Fe(II) and excess iodide given above used the same approach as that of Sanial et al. (n.d.), but their ${ }^{228} \mathrm{Ra}$ flux was ultimately computed from a model by Kwon et al. (2014) that has a resolution of $2^{\circ}$ latitude and $2^{\circ}$ longitude; it is rather course. Therefore, to compare these horizontal fluxes from the shelf with the water column the rates at Stations $5(50 \mathrm{~km}$ from the shelf break) and $9(1200 \mathrm{~km}$ from the shelf), the water column estimates should be scaled to an equivalent $2^{\circ}$ (i.e., $222 \mathrm{~km}$ length of the shelf) scale by converting them into values for the OMZ "box." The Station 5 shelf/slope box is $222 \mathrm{~km}$ wide, $425 \mathrm{~m}$ deep, and $625 \mathrm{~km}$ long (half the distance from Station 5 to 0 plus $50 \mathrm{~km})$, or a volume of $5.9 \times 10^{4} \mathrm{~km}^{3}\left(5.9 \times 10^{13} \mathrm{~m}^{3}\right)$. Similarly, the Station 9 offshore box is $222 \mathrm{~km}$ wide, $489 \mathrm{~m}$ deep, and $625 \mathrm{~km}$ long, giving a $6.8 \times 10^{13} \mathrm{~m}^{3}$ volume of OMZ water. Placing the steady state $4.8 \pm 0.4 \times 10^{-4} \mathrm{nmol} \mathrm{Fe} 1^{-1} \mathrm{~d}^{-1}$ rate computed above into the Station 5 box yields $2.8 \pm 0.2 \times 10^{4} \mathrm{~mol} \mathrm{Fe} \mathrm{d}^{-1}$, while for the Station 9 box the computed rate of $0.8 \pm 0.4 \times 10^{-4} \mathrm{nmol} \mathrm{Fe}$ $\mathrm{l}^{-1} \mathrm{~d}^{-1}$ would mean $0.5 \pm 0.3 \times 10^{4} \mathrm{~mol} \mathrm{Fe} \mathrm{d}^{-1}$ are required. The sum of these two boxes is $3.3 \pm 0.4 \times 10^{4} \mathrm{~mol} \mathrm{Fe} \mathrm{d}^{-1}$ (Table 1), the amount of Fe(II) that must be delivered to the offshore Peru margin OMZ to maintain the observed maxima. Thus, the shelf flux of $\mathrm{Fe}(\mathrm{II})$ calculated independently $\left(2.3 \pm 0.8 \times 10^{5} \mathrm{~mol} \mathrm{~d}^{-1}\right)$ is sufficient to account for the observation of $\mathrm{Fe}(\mathrm{II})$ in a suboxic water column that is not sufficiently reducing to explain its presence without invoking a mechanism for in situ production (Table 1). Sanial et al. (n.d.) also reported higher ${ }^{228} \mathrm{Ra}$ in deep waters, suggesting lateral advection could give rise to the elevated concentrations of $\mathrm{Fe}(\mathrm{II})$ observed around $800 \mathrm{~m}$ at Stations 1 and 5 . However, they found even higher ${ }^{228} \mathrm{Ra}$ associated with a maximum in total dissolved Fe reported by Resing et al. (2015) centered around $2000 \mathrm{~m}$. Our data show that feature contained no detectable Fe(II).

Calculations identical to those for Fe(II), but applied to the excess iodide

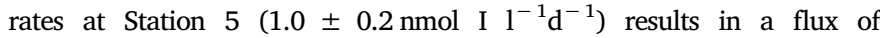
$5.9 \pm 1.2 \times 10^{7} \mathrm{~mol} \mathrm{I} \mathrm{d}^{-1}$ for the Station $5 \mathrm{OMZ}$ box and $2.7 \pm 1.4 \times 10^{7} \mathrm{~mol} \mathrm{I} \mathrm{d}^{-1}\left(6.8 \times 10^{13} \mathrm{~m}^{-3} \times 0.4 \pm 0.2 \times 10^{3} \mathrm{nmol} \mathrm{I}\right.$ $\mathrm{m}^{-3} \mathrm{~d}^{-1}$ ) for the Station 9 OMZ box. The sum of these two requires $8.6 \pm 1.8 \times 10^{7} \mathrm{~mol} \mathrm{I} \mathrm{d}^{-1}$ of excess iodide to be horizontally transported into the Peru margin OMZ to maintain steady state conditions (Table 1). This value is matched by the shelf flux of $7.5 \pm 3.0 \times 10^{7} \mathrm{~mol} \mathrm{I} \mathrm{d}^{-1}$ (Table 1), showing all of the excess iodide in the suboxic water column at offshore stations can be delivered from the Peru margin. The observation (Fig. 4a and d) that excess iodide persists farther out into the open ocean than does Fe(II) argues that its oxidation rate must be slower, but also explains why the shelf and offshore fluxes can so closely match while the shelf $\mathrm{Fe}$ (II) flux must be larger to overcome its oxidative loss.

The approach used in this study can be applied to other redox sensitive elements as well. Hawco et al. (2016) measured Co on the same cruise and identified a plume within the upper OMZ that was coincident with the Fe(II) and iodide maxima reported here. The source appears to be the very high concentrations of dissolved Co over the shelf, a persistent feature observed previously (Saito et al., 2004). This Co feature shows remarkable similarities to dissolved Fe(II), suggesting control by similar in situ and advective/diffusive processes. It seems likely that other redox couples such as $\mathrm{Cr}(\mathrm{III}) / \mathrm{Cr}(\mathrm{VI})$ might be active in this part of the water column as well.

\section{Conclusions}

This redox study highlights the value of the GEOTRACES multi parameter approach by showing how the combination of redox speciation, ${ }^{228} \mathrm{Ra}$ Sanial et al., n.d. and ${ }^{7} \mathrm{Be}$ data (Kadko, 2017), particle chemistry (Heller et al., 2017), and total dissolved metal data (Resing et al., 2015) provides insight into the unique chemistry of OMZ/suboxic waters. The Peru OMZ is a dynamic redox environment, with multiple redox states of As, Fe, I, and N co-existing in the "absence" of oxygen. 
The most reducing regime is centered around the secondary nitrite maximum, coincident with the intense microbial community at these depths (Ulloa et al., 2012). But, this study provides the first evidence that shelf processes exert strong influence on the redox characteristics of this feature extending well offshore (Table 1). This shelf signal is unambiguous for excess iodide and likely the case for Fe(II). The formation of $\mathrm{Fe}(\mathrm{II})$ within shelf sediments presumably occurs in the absence of nitrate and is consistent with Fe(III) utilization as a terminal electron acceptor. The subsequent fate of Fe(II) as it is transported offshore is determined not by thermodynamics, but by oxidation kinetics with nitrate or nitrite (Scholz et al., 2016). The formation of $\mathrm{Fe}$ oxides throughout the OMZ west of the shelf slope break on GP16 (Heller et al., 2017) clearly shows oxidation does occur in the OMZ. A major gap in our knowledge is that there are no measurements of the rates of these processes within the OMZ to compare with rates measured by Scholz et al. (2016) over the shelf itself. We do not know if Fe (II) oxidation is a slow, unidirectional process, or if dynamic redox cycling occurs.

The Peru OMZ studies show that there is no unique p $\varepsilon$ that could be quantified to explain all of our observations. Indeed, the concept of $p \varepsilon$ presumes thermodynamic equilibrium, but many studies clearly demonstrate that redox species within anoxic and suboxic waters are controlled by their rates of oxidation and reduction (e.g., Cutter, 1991). Nevertheless, $p \varepsilon$ is still a useful concept because it forced us to search for explanations for the anomalies, in particular the presence of Fe(II). Our findings reflect the importance of kinetics and transport processes on fully explaining the chemical regime within oxygen minimum and suboxic zones.

\section{Acknowledgments}

The authors thank Claire Parker, Cheryl Zurbrick, and Laura Richardson for their tireless work in the GEOTRACES clean van acquiring our samples, Susan Becker and Melissa Miller of the Scripps Institution of Oceanography's Ocean Data Facility for the nutrient and oxygen data, and Bettina Sohst for ODV plots. Finally, we sincerely thank Bill Jenkins at WHOI for error checking our modeling approaches, and the three reviewers of the manuscript whose suggestions were greatly appreciated. The WHOI postdoctoral scholar V. Sanial was supported by the Center for Marine and Environmental Radioactivity (CMER). This work was supported by US National Science Foundation grants OCE-1235328 to G. Cutter, OCE-1260279 to J. Moffett, and OCE1232660 to M. Charette for the Ra work.

\section{References}

Armstrong, F.A., Stearns, C.R., Strickland, J.D., 1967. The measurement of upwelling and subsequent biological process by means of the Technicon Autoanalyzer ${ }^{\oplus}$ and associated equipment. Deep Sea Res. Oceanogr. Abstr. 14, 381-389.

Bernhardt, H., Wilhelms, A., 1967. The continuous determination of low level iron, soluble phosphate and total phosphate with the AutoAnalyzer. In: Technicon Symposia. vol. 1. pp. 385-389.

Bruland, K.W., Rue, E.L., Smith, G.J., DiTullio, G.R., 2005. Iron, macronutrients and diatom blooms in the Peru upwelling regime: brown and blue waters of Peru. Mar. Chem. 93 (2), 81-103.

Canfield, D.E., et al., 2010. A cryptic sulfur cycle in oxygen-minimum-zone waters off the Chilean coast. Science 330 (6009), 1375-1378.

Carpenter, J.H., 1965. The Chesapeake Bay institute technique for the Winkler dissolved oxygen method. Limnol. Oceanogr. 10 (1), 141-143.

Chapman, P., Liss, P.S., 1977. The effect of nitrite on the spectrophotometric determination of iodate in seawater. Mar. Chem. 5, 243-249.

Charette, M.A., et al., 2016. Coastal ocean and shelf-sea biogeochemical cycling of trace elements and isotopes: lessons learned from GEOTRACES. Phil. Trans. R. Soc. A 374 (2081).

Codispoti, L.A., Packard, T., 1980. Denitrification rates in the eastern tropical South Pacific. J. Mar. Res. 38, 453-477.

Codispoti, L., Yoshinari, T., Devol, A., 2005. Suboxic respiration in the oceanic water column. In: Del Giorgio, P., Williams, P. Le B. (Eds.), Respiration in Aquatic Ecosystems. Oxford University Press, pp. 225-247.

Craig, H., 1969. Abyssal carbon and radiocarbon in the Pacific. J. Geophys. Res. 74, 5491-5506.
Croot, P.L., Laan, P., 2002. Continuous shipboard determination of Fe(II) in polar waters using flow injection analysis with chemiluminescence detection. Anal. Chim. Acta 466 (2), 261-273.

Culberson, C.H., 1994. Dissolved oxygen. In: WOCE Operations Manual. WHP Operations and Methods: July 1991. vol. 1. WHP Office Report WHPO 91, pp. 15.

Cutter, G.A., 1991. Dissolved arsenic and antimony in the black-sea. Deep-Sea Res. A 38, S825-S843.

Cutter, G.A., 2005. Biogeochemistry: now and into the future. Palaeogeogr. Palaeoclimatol. Palaeoecol. 219, 191-198.

Cutter, G.A., Bruland, K.W., 2012. Rapid and non-contaminating sampling system for trace elements in global ocean surveys. Limnol. Oceanogr. Methods 10, 425-436.

Cutter, G.A., Cutter, L.S., 2006. The biogeochemistry of arsenic and antimony in the North Pacific Ocean. Geochem. Geophys. Geosyst. 7, Q05M08. http://dx.doi.org/10. 1029/2005GC001159.

Cutter, L.S., Cutter, G.A., San Diego-McGlone, M.L.C., 1991. Simultaneous determination of inorganic arsenic and antimony species in natural waters using selective hydride generation with gas chromatography/photoionization detection. Anal. Chem. 63, 1138-1142.

Czeschel, R., Stramma, L., Weller, R.A., Fischer, T., 2015. Circulation, eddies, oxygen, and nutrient changes in the eastern tropical South Pacific Ocean. Ocean Sci. 11 (3), 455-470.

Dale, A.W., Nickelsen, L., Scholz, F., Hensen, C., Oschlies, A., Walmann, K., 2015. A revised global estimate of dissolved iron fluxes from marine sediments. Glob. Biogeochem. Cycles 29, 691-707.

Deutsch, C., Gruber, N., Key, R.M., Sarmiento, J.L., Ganachaud, A., 2001. Denitrification and N-2 fixation in the Pacific Ocean. Glob. Biogeochem. Cycles 15 (2), 483-506.

Elrod, V.A., Berelson, W.M., Coale, K.H., Johnson, K.S., 2004. The flux of iron from continental shelf sediments: a missing source for global budgets. Geophys. Res. Lett. 31 (12), L12307. http://dx.doi.org/10.1029/2004GL020216.

Farrenkopf, A.M., Luther, G.W., 2002. Iodine chemistry reflects productivity and denitrification in the Arabian Sea: evidence for flux of dissolved species from sediments of western India into the OMZ. Deep-Sea Res. II 49 (12), 2303-2318.

Farrenkopf, A.M., Dollhopf, M.E., Chadhain, S.N., Luther, G.W., Nealson, K.H., 1997. Reduction of iodate in seawater during Arabian Sea shipboard incubations and in laboratory cultures of the marine bacterium Shewanella putrefaciens strain MR-4. Mar. Chem. 57 (3-4), 347-354.

Fiedler, P.C., Talley, L.D., 2006. Hydrography of the eastern tropical Pacific. A review. Prog. Oceanogr. 69 (2-4), 143-180. http://dx.doi.org/10.1016/j.pocean.2006.03. 008.

Hawco, N.J., Ohnemus, D.C., Resing, J.A., Twining, B.S., Saito, M.A., 2016. A dissolved cobalt plume in the oxygen minimum zone of the eastern tropical South Pacific. Biogeosciences 13 (20), 5697-5717. http://dx.doi.org/10.5194/bg-13-5697-2016.

Heller, M.I., Lam, P.J., Moffett, J.W., Till, C.P., Lee, J.M., Toner, B.M., Marcus, M.A., 2017. Accumulation of Fe oxyhydroxides in the Peruvian oxygen deficient zone implies non-oxygen dependent Fe oxidation. Geochim. Cosmochim. Acta XX.

Hong, H.S., Kester, D.R., 1986. Redox state of iron in the offshore waters of Peru. Limnol. Oceanogr. 31, 512-524.

Hopkinson, B.M., Barbeau, K.A., 2007. Organic and redox speciation of iron in the eastern tropical North Pacific suboxic zone. Mar. Chem. 106 (1-2), 2-17.

Kadko, D., 2017. Upwelling and primary production during the U.S. GEOTRACES East Pacific zonal transect. Glob. Biogeochem. Cycles 31. http://dx.doi.org/10.1002/ 2016 GB005554.

King, D.W., Lounsbury, H.A., Millero, F.J., 1995. Rates and mechanism of Fe(II) oxidation at nanomolar total iron concentrations. Environ. Sci. Technol. 29 (3), 818-824.

Kondo, Y., Moffett, J.W., 2015. Iron redox cycling and subsurface offshore transport in the eastern tropical South Pacific oxygen minimum zone. Mar. Chem. 168, 95-103.

Kwon, E.Y., Kim, G., Primeau, F., Moore, W.S., Cho, H.-M., DeVries, T., Sarmiento, J.L., Charette, M.A., Cho, Y.-K., 2014. Global estimate of submarine groundwater discharge based on an observationally constrained radium isotope model. Geophys. Res. Lett. 41 (23) (2014GL061574). https://doi.org/10.1002/2014GL061574.

Lam, P.J., Bishop, J.K., 2008. The continental margin is a key source of iron to the HNLC North Pacific Ocean. Geophys. Res. Lett. 35 (7), L07608. http://dx.doi.org/10.1029/ 2008 GL033294.

Lipshultz, F.S.C., Ward, B.B., Codispoti, L.A., Friederich, G., Elkins, J.W., 1990. Bacterial transformations of inorganic nitrogen in the oxygen deficient waters of the eastern tropical South Pacific Ocean. Deep-Sea Res. 37, 1513-1541.

Luther, G.W., Campbell, T., 1991. Iodine speciation in the water column of the Black Sea. Deep Sea Res. Part A. Oceanogr. Res. Papers 38, S875-S882.

Luther III, G.W., Swartz, C.B., Ullman, W.J., 1988. Direct determination of iodide in seawater by cathodic stripping square wave voltammetry. Anal. Chem. 60 (17), 1721-1724.

Matear, R.J., Hirst, A.C., 2003. Long-term changes in dissolved oxygen concentrations in the ocean caused by protracted global warming. Glob. Biogeochem. Cycles 17 (4).

Moffett, J.M., 2001. Transformations amongst different forms of iron in seawater. In: Hunter, K., Turner, D. (Eds.), Biogeochemistry of Iron in Seawater. IUPAC Series on Analytical and Physical Chemistry of Environmental Systems, vol. 7. pp. 343-373.

Moffett, J.W., Goepfert, T., Naqvi, S.W.A., 2007. Reduced iron associated with secondary nitrite maxima in the Arabian Sea. Deep-Sea Res. I 54, 1341-1349.

Moffett, J.W., et al., 2015. Biogeochemistry of iron in the Arabian Sea. Limnol. Oceanogr. 60 (5), 1671-1688.

Moore, J.K., Braucher, O., 2008. Sedimentary and mineral dust sources of dissolved iron to the world ocean. Biogeosciences 5, 631-656.

Naqvi, S.W.A., Shailaja, M.S., 1993. Activity of the respiratory electron-transport system and respiration rates within the oxygen minimum layer of the Arabian Sea. Deep-Sea Res. Part II Top. Stud. Oceanogr. 40 (3), 687-695.

Naqvi, S.W.A., Noronha, R.J., Somasundar, K., Sengupta, R., 1990. Seasonal-changes in 
the denitrification regime of the Arabian Sea. Deep-Sea Res. A 37 (4), 593-611.

Noffke, A., Hensen, C., Sommer, S., Scholz, F., Bohlen, L., Mosch, T., Graco, M., Walmann, K., 2012. Benthic iron and phosphorus fluxes across the Peruvian oxygen minimum zone. Limnol. Oceanogr. 57 (3), 851-867. http://dx.doi.org/10.4319/1o.2012.57.3. 0851.

Ohnemus, D.C., Rauschenberg, S., Cutter, G.A., Fitzsimmons, J.N., Sherrell, R.M Twining, B.S., 2016. Elevated trace metal content of prokaryotic communities associated with marine oxygen deficient zones. Limnol. Oceanogr. 16-24. http://dx.doi. org $/ 10.1002 /$ lno.10363.

Oremland, R.S., Stolz, J.F., 2003. The ecology of arsenic. Science 300 (5621), 939-944.

Passier, H.F., Luther, G.W., De Lange, G.J., 1997. Early diagenesis and sulphur speciation in sediments of the Oman Margin, northwestern Arabian Sea. Deep-Sea Res. II Top. Stud. Oceanogr. 44 (6), 1361-1380.

Peterson, M.L., Carpenter, R., 1983. Biogeochemical processes affecting total arsenic and arsenic species distributions in an intermittently anoxic fjord. Mar. Chem. 12 (4), 295-321.

Radford-Knoery, J., Cutter, G.A., 1993. Determination of carbonyl sulfide and hydrogensulfide species in natural-waters using specialized collection procedures and gaschromatography with flame photometric detection. Anal. Chem. 65 (8), 976-982.

Raiswell, R., Canfield, D.M., 2012. The iron biogeochemical cycle past and present. Geochem. Perspect. 1 (1), 232

Redfield, A., Ketchum, B.H., Richards, F.A., 1963. The influence of organisms on the chemistry of seawater. In: Hill, M.N. (Ed.), The Sea. Academic Press, pp. 26-77.

Resing, J.A., Sedwick, P.N., German, C.R., Jenkins, W.J., Moffett, J.W., Sohst, B.M., Tagliabue, A., 2015. Basin-scale transport of hydrothermal dissolved metals across the South Pacific Ocean. Nature 523 (7559), 200-203. http://dx.doi.org/10.1038/ nature14577.

Revsbech, N.P., et al., 2009. Determination of ultra-low oxygen concentrations in oxygen minimum zones by the STOX sensor. Limnol. Oceanogr. Methods 7, 371-381.

Richards, F.A., 1965. Anoxic basins and fjords. In: Riley, J.P., Skirrow, G. (Eds.), Chemical Oceanography. Academic Press, pp. 611-645.

Rose, A.L., Waite, T.D., 2001. Chemiluminescence of luminol in the presence of iron(II) and oxygen: oxidation mechanism and implications for its analytical use. Anal. Chem. 73 (24), 5909-5920.

Roy, E.G., Wells, M.L., King, D.W., 2008. Persistence of iron(II) in surface waters of the western subarctic pacific. Limnol. Oceanogr. 53 (1), 89-98.

Rue, E.L., Smith, G.J., Cutter, G.A., Bruland, K.W., 1997. The response of trace element redox couples to suboxic conditions in the water column. Deep-Sea Res. I 44 (1) 113-134.

Saito, M.A., Moffett, J.W., DiTullio, G.R., 2004. Cobalt and nickel in the Peru upwelling region: a major flux of labile cobalt utilized as a micronutrient. Global Biogeochem. Cycle 18 (4), GB4030. http://dx.doi.org/10.1029/2003GB002216.

Sanial V, Kipp L., Henderson P.B., van Beek P., Reyss, J.L., Hammond, D.E., Hawco, N., Saito, M., Resing, J., Sedwick, P., Moore, W.S., and Charette, M.A. Radium-228 as a tracer of dissolved trace element inputs from the peruvian continental margin Mar.
Chem..

Scholz, F., McManus, J., Mix, A.C., Hensen, C., Schneider, R.R., 2014. The impact of ocean deoxygenation on iron release from continental margin sediments. Nat. Geosci. 7, 433-437.

Scholz, F., Löscher, C.R., Fiskal, A., Sommer, S., Hensen, C., Lomnitz, U., Wuttig, K. Göttlicher, J., Kossel, E., Steininger, R., Canfield, D.E., 2016. Nitrate-dependent iron oxidation limits iron transport in anoxic ocean regions. Earth Planet. Sci. Lett. 454, 272-281. http://dx.doi.org/10.1016/j.epsl.2016.09.025.

Schunck, H., et al., 2013. Giant hydrogen sulfide plume in the oxygen minimum zone off Peru supports chemolithoautotrophy. PLoS One 8 (8).

Shaked, Y., 2008. Iron redox dynamics in the surface waters of the Gulf of Aqaba, Red Sea. Geochim. Cosmochim. Acta 72 (6), 1540-1554.

Spencer, D.W., Brewer, P.G., 1971. Vertical advection diffusion and redox potentials as controls on distribution of manganese and other trace metals dissolved in waters of Black Sea. J. Geophys. Res. 76 (24), 5877-5892.

Stramma, L., Johnson, G.C., Sprintall, J., Mohrholz, V., 2008. Expanding oxygenminimum zones in the tropical oceans. Science 320, 655-658.

Stumm, W., Morgan, J.J., 1996. Aquatic Chemistry: Chemical Equilibria and Rates in Natural Waters. John Wiley \& Sons.

Tian, R.C., Nicolas, E., 1995. Iodine speciation in the northwestern Mediterranean Sea, method and vertical profile. Mar. Chem. 48 (2), 151-156.

Tiano, L., et al., 2014. Oxygen distribution and aerobic respiration in the north and south eastern tropical Pacific oxygen minimum zones. Deep-Sea Res. I 94, 173-183.

Ulloa, O., Canfield, D.E., DeLong, E.F., Letelier, R.M., Stewart, F.J., 2012. Microbial oceanography of anoxic oxygen minimum zones. Proc. Natl. Acad. Sci. U. S. A. 109 (40), 15996-16003.

Van der Weijden, C.H., Middelburg, J.J., De Lange, G.J., Van der Sloot, H.A., Hoede, D. Woittiez, J.R., 1990. Profiles of the redox-sensitive trace elements As, Sb, V, Mo and $\mathrm{U}$ in the Tyro and Bannock Basins (eastern Mediterranean). Mar. Chem. 31 (1-3), 171-186.

Vedamati, J., Goepfert, T., Moffett, J.W., 2014. Iron speciation in the eastern tropical South Pacific oxygen minimum zone off Peru. Limnol. Oceanogr. 59 (6), 1945-1957. http://dx.doi.org/10.4319/lo.2014.59.6.1945.

van de Vossenberg, J., Rattray, J.E., Geerts, W., Kartal, B., van Niftrik, L., van Donselaar, E.G., et al., 2008. Enrichment and characterization of marine anammox bacteria associated with global nitrogen gas production. Environ. Microbiol. 10, 3120-3129.

Wong, G.T.F., Brewer, P.G., 1974. The determination and distribution of iodate in South Atlantic waters. J. Mar. Res. 32 (1), 25-36.

Wong, G.T.F., Brewer, P.G., 1977. Marine chemistry of iodine in anoxic basins. Geochim. Cosmochim. Acta 41 (1), 151-159.

Wong, G.T., Piumsomboon, A.U., Dunstan, W.M., 2002. The transformation of iodate to iodide in marine phytoplankton cultures. Mar. Ecol. Prog. Ser. 237, 27-39.

Wurl, O., Zimmer, L., Cutter, G.A., 2013. Arsenic and phosphorus biogeochemistry in the ocean: arsenic species as proxies for P-limitation. Limnol. Oceanogr. 58, 729-740. 